\title{
The Contractual Principle of Good Faith AND THE DUTY OF HONESTY IN BHASIN V. HRYNEW
}

\author{
SHANNON O'BYRNE AND RONNIE COHEN*
}

\begin{abstract}
This article explores the Supreme Court of Canada's 2014 decision in Bhasin v. Hrynew. This includes an assessment of the new duty of honesty in contractual performance and the newly identified organizing principle of good faith. The authors also discuss contracting out of the duty of honesty - which Bhasin itself raises as a possibility - by assessing both Canadian and American law on point, including the Uniform Commercial Code. The article concludes that Bhasin's largest and most lasting contribution is likely in how it expressly legitimates and defends the role of good faith in the common law of contract.
\end{abstract}

\section{TABLE OF CONTENTS}

I. INTRODUCTION $\ldots \ldots \ldots \ldots \ldots \ldots \ldots \ldots \ldots \ldots \ldots \ldots \ldots \ldots \ldots \ldots \ldots \ldots$

II. BHASIN AT THE TRIAL, APPELLATE, AND SUPREME COURT OF CANAdA LEVELS $\ldots \ldots \ldots \ldots \ldots \ldots \ldots \ldots 4$

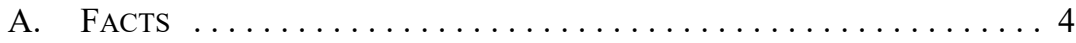

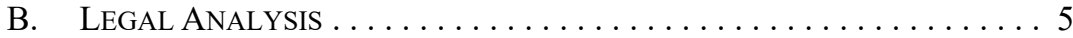

III. Good Faith as an ORganizIng PRINCIPLE $\ldots \ldots \ldots \ldots \ldots \ldots \ldots 11$

IV. RELAXING THE REQUIREMENTS OF THE BHASIN DUTY OF HONESTY $\ldots \ldots 16$

V. THE OBLIGATION OF GOOD FAITH UNDER AMERICAN CONTRACT LAW AND ITS RELAXATION $\ldots \ldots \ldots \ldots \ldots \ldots 21$

A. GoOd FaITH AND THE UCC $\ldots \ldots \ldots \ldots \ldots \ldots \ldots \ldots \ldots \ldots$

B. Good Faith AND the Restatement (SECOND) OF CONTRACTS $\ldots 23$

C. Defining the Obligation of Good Faith . . . . . . . . . . 24

D. RELAXING THE OBLIGATION OF GoOd FAith $\ldots \ldots \ldots \ldots \ldots 26$

VI. CONCLUSION ................................ 33

\section{INTRODUCTION}

Assessments offered soon after the Supreme Court of Canada's 2014 decision in Bhasin v. Hrynew ${ }^{1}$ regarded it as signaling a major shift in how the Canadian common law of

Professor Shannon Kathleen O’Byrne, Faculty of Law, University of Alberta and Professor Ronnie Cohen, Luter School of Business, Christopher Newport University. In the interests of full disclosure, we note that Parlee McLaws, LLP represented the defendants at trial and Shannon O'Byrne's spouse is a partner at that firm. We would like to thank Professors Tamara Buckwold and David Percy of the Faculty of Law, University of Alberta; Professor John McCamus of Osgoode Hall Law School and affiliated scholar with Davies, Ward, Phillips and Vineberg LLP; Professor Paul MacMahon of the London School of Economics; and Professor Stephen Sepinuck of Gonzaga School of Law for providing very helpful comments on an earlier version of this article. We are also grateful to Professors Gail Henderson and Eric Adams of the Faculty of Law, University of Alberta, for insights offered during conversation as well as to Angela Swan (Counsel) of Aird \& Berlis LLP; Professor Michael O'Hara of the University of Nebraska, Omaha; Janine Hiller of Virginia Tech; and John Norwood from the University of Arkansas for their very helpful email communications. Finally, we acknowledge with gratitude the outstanding research assistance of Kathleen O'Driscoll (undergraduate law at the University of Alberta); Sean McGinnis (undergraduate law at McGill University); and Grant Kaylor (law reference librarian at the University of Alberta). This article, in an earlier form, was originally prepared for presentation at the National Judicial Institute's Civil Law Seminar held in May 2015. 2014 SCC 71, [2014] 3 SCR 494 [Bhasin SCC]. 
contract is to be conceptualized. At that time, Bhasin was described variously as a "blockbuster," as "ground-breaking,"3 as effecting a "dramatic change"4 in the law, as well as having "massive" and "significant" implications — to give just a few examples.

Whether these early reviews prove to be prescient is currently an open question. On the one hand, the approach in Bhasin is radical, at least from a common law perspective. Eschewing contract law's traditional ill-regard for good faith, ${ }^{7}$ the Supreme Court of Canada (in a unanimous decision written by Justice Cromwell) ruled that "good faith contractual performance is a general organizing principle of the common law of contract which underpins and informs the various rules in which the common law, in various situations and types of relationships, recognizes obligations of good faith contractual performance."8 The Court is careful not to articulate the consequences or limits of this principle in its broadest form. Instead, it offers some of the principle's content in the context of those situations or relationships, namely that parties must act "honestly and reasonably and not capriciously or arbitrarily" in fulfilling their contractual obligations. ${ }^{9}$ One manifestation or emanation of this aspect of the organizing principle is the creation by the Supreme Court of Canada of a new "common law duty which applies to all contracts to act honestly in the performance of contractual obligations." 10

The Court's intent in recognizing good faith as an organizing principle is to clarify and improve the common law which has historically approached good faith in a fragmentary, even suspiciously-minded way - an approach which, in turn, has generated a body of law described by the Court as "piecemeal, unsettled and unclear." Canada instructs that the good faith principle works to provide the "standard" or context or backdrop against which common law rules and doctrines - both old and new — can be recognized, generated, and espoused. ${ }^{12}$ In short, the organizing principle of good faith is intended to help bench and bar "understand and develop the law in a coherent and principled

Cristin Schmitz, "Contract law blockbuster leaves counsel with lingering questions," The Lawyers Weekly (28 November 2014), online: <www.lawyersweekly.ca/articles/2267>.

$3 \quad$ Ibid. See also Jacquie McNish, "Supreme Court of Canada ruling makes honesty the law for businesses," The Globe and Mail (14 November 2014), online: <www.theglobeandmail.com/report-onbusiness/supreme-court-of-canada-ruling-makes-honesty-the-law-for-businesses/article21583597/>. Stephen Perry, Andrew Currier \& Damian Rolfe, "SCC Recognizes an Organizing Principle of Good Faith in Contract Law and a New Duty of Honest Contractual Performance" (30 November 2014), PCK Reporter (blog), online: <www.pckip.com/summary/scc-recognizes-an-organizing-principle-of-goodfaith-in-contract-law-and-a-new-duty-of-honest-contra>.

David Dias, "SCC establishes duty of honesty between contracting parties" (13 November 2014) Canadian Lawyer (blog), online: <www.canadianlawyermag.com/legalfeeds/2379/scc-establishes-dutyof-honesty-between-contracting-parties.html> (quoting the view of Brandon Kain, co-counsel for Mr. Bhasin).

6 Marco P Falco, “'Be Honest': Supreme Court Of Canada Recognizes The Duty Of Honest Contractual Performance" Torkin Manes LegalWatch (17 November 2014), online: <www.mondaq.com/canada/x/ 354442/Contract+Law/Be+Honest+Supreme+Court+Of>.

7 Bhasin SCC, supra note 1 (the Supreme Court of Canada memorably references Professor Swan's observation that the common law has in fact "taken a 'kind of perverted pride' in the absence of any general notion of good faith, as if accepting that notion "would be admitting to the presence of some kind of embarrassing social disease"” at para 36, citing John Swan, "Whither Contracts: A Retrospective and Prospective Overview", in Special Lectures of the Law Society of Upper Canada 1984 - Law in Transition: Contracts (Don Mills: Richard De Boo Publishers, 1984) 125 at 148.

Bhasin SCC, supra note 1 at para 33 [emphasis added].

Ibid at para 63.

Ibid at para 33.

Ibid at para 59.

Ibid at para 64. 
way." ${ }^{\prime 13}$ Recognition of a duty of honesty in contractual performance is simply the first example of applying this new approach, with lower courts expressly mandated by the Supreme Court of Canada to continue the project of amplification going forward.

But, on the other hand, and in contrast to earliest reviews, it has also been argued that express recognition of the good faith principle in Bhasin is unlikely to revolutionalize contract law in common law Canada at all. As Andrea Bolieiro observes: "To all those raising the spectre of uncertainty, fear not: the organizing principle of good faith will not break contract law." ${ }^{14}$ Indeed, Justice Cromwell himself notes that claims based on good faith will likely fail unless they fall within existing categories and relationships wherein the Canadian common law has already determined that good faith obligations lie. ${ }^{15}$ Put another way, courts are admonished by Justice Cromwell to address injustice but not to stray too far from existing confines:

\begin{abstract}
The application of the organizing principle of good faith to particular situations should be developed where the existing law is found to be wanting and where the development may occur incrementally in a way that is consistent with the structure of the common law of contract and gives due weight to the importance of private ordering and certainty in commercial affairs. ${ }^{16}$
\end{abstract}

Expressly relying on Justice Cromwell's analysis above, Justice Veit of the Alberta Court of Queen's Bench observed in the post-Bhasin decision of Kramer's Technical Services Inc. v. Eco-Industrial Business Park Inc. as follows: the organizing principle of good faith is "already manifest in our law of contract and that, generally, issues relating to the good faith principle in contract law will continue to be dealt with as they have been in the existing law." 17

This article will explore the implications of Bhasin over several parts. Part II provides some brief analysis of the case at the trial, appellate, and Supreme Court of Canada levels as well as discusses the new duty of honesty in contractual performance. Part III considers in more detail the principle of good faith identified by the Court and locates that principle in relation to other contractual doctrines and relationships discussed by the Court in Bhasin as well as the contractual term of good faith. Part IV shifts gears to consider contracting out of the new duty of honesty pursuant to existing Canadian law. Part V offers an assessment of this same question but based on American contract law, including the Uniform Commercial Code (UCC). This is to follow a suggestion by Justice Cromwell that Canadian law might

\footnotetext{
Ibid.

Andrea M Bolieiro, "Bhasin v Hrynew and the principle of good faith in contracts: Moving towards a modern view of commercial relationships" (2015) 33:4 Adv J 23 at 29.

Bhasin SCC, supra note 1 at para 66.

Ibid.

2015 ABQB 59, 2015 ABQB 59 (CanLII) at para 35. According to the Court, the new principle developed in Bhasin SCC is that "a contracting party cannot actively lie to the other contract party(ies)" at para 35. See also Justice Myer's comment in Warburg-Stuart Management Corp v DBG Holdings Inc, 2015 ONSC 1594, 2015 ONSC 1594 (CanLII) that "[i]t seems to me that Supreme Court of Canada was very careful to make a minimal change, if any, to the common law in Bhasin" at para 38. As yet another example, consider this assessment from Justice Dunphy in Addison Chevrolet Buick GMC Ltdv General Motors of Canada Ltd, 2015 ONSC 3404, 2015 ONSC 3404 (CanLII) at para 116:

Bhasin is no authority for unbridled creativity in the creation from whole cloth of obligations in a contractual context which the parties have not provided for or have addressed in a fashion which one party regrets in hindsight. Good faith and honesty are the boundaries of the field on which the contractual relationship is negotiated and performed.
} 
learn from American experience on this point. ${ }^{18}$ Part VI offers only modest conclusions, especially because the newly identified principle and duty are very much in their early days. What they actually mean is in the hands of the Canadian judiciary - who have been brought into a definitional role by the Supreme Court - thereby engaging what is likely to be a lengthy, sometimes large, and always careful process of both retention and reformulation.

\section{Bhasin at the Trial, Appellate, AND SUPREME COURT OF CANADA LEVELS}

\section{A. FACTS $^{19}$}

The defendant, Canadian American Financial Corp (Can-Am), was a marketer of education savings plans to investors. Can-Am accomplished its sales through enrollment directors - that is, small business owners - who would earn compensation and bonuses by relying on building their own sales forces. The plaintiff, Mr. Bhasin (through his company), was just such an enrollment director. The relationship between Bhasin and Can-Am was governed by a commercial dealership agreement (specifically, a director's enrollment agreement) which began in 1998 and superseded a previous agreement between the parties that began in 1989. The arrangement between Can-Am and Bhasin was not one of franchisorfranchisee though it shared some of the same features. Bhasin owed a fiduciary duty to CanAm and could only sell Can-Am products. He was also forbidden to sell, transfer, or merge his operation without Can-Am's consent, which under the agreement could not be unreasonably withheld. For its part, Can-Am owned the customer lists, attended to the implementation of central policies binding on all enrollment directors, and handled branding. Included in the agreement between Bhasin and Can-Am was an expiry and renewal clause which provided as follows:

3.3 The term of this Agreement shall be for a period of three years from the date hereof (the "Initial Term") and thereafter shall be automatically renewed for successive three year periods (a "Renewal Term"), subject to earlier termination as provided for in section 8 hereof, unless either [Can-Am] or the Enrollment Director notifies the other in writing at least six months prior to expiry of the Initial Term or any Renewal Term that the notifying party desires expiry of the Agreement, in which event the Agreement shall expire at the end of such Initial Term or Renewal Term, as applicable.

Problems between the parties began to emerge when a competitor of Bhasin, one Mr. Hrynew, moved his agency to Can-Am. Can-Am promised Hrynew opportunities to merge with other agencies and, in fact, delivered on that commitment. Beyond this, Hrynew was very interested in capturing Bhasin's market and pressured Can-Am to force the merger with the veiled threat that he would otherwise leave. Bhasin, for his part, had no interest in a merger. Matters worsened when, in response to concerns by the Alberta Securities Commission regarding enrollment director compliance with securities legislation, Can-Am appointed Hrynew to conduct audits of the enrollment directors in its stable. Bhasin, one of Can-Am's top enrollment directors, was very concerned that Hrynew, a competitor, would

18 Bhasin SCC, supra note 1 at para 77.

19 This summary of facts is based on the one offered by the Supreme Court of Canada in Bhasin SCC, ibid at paras $2-14$. 
be given access to Bhasin's confidential business information. Moreover, Can-Am misled Bhasin on a number of fronts including being equivocal about whether the merger with Hrynew was a "done deal" even though, in plans outlined to the Securities Commission, CanAm committed that Bhasin would be working for Hrynew's agency. Matters came to a head when Bhasin dug in his heels and refused to allow Hrynew to continue his audit, having previously refused a merger. Can-Am threatened not to renew the agreement and in fact gave notice of expiry in accordance with clause 3.3. The aftermath for Bhasin was that he lost the value of his business as well as the majority of his sales staff who went over to work for Hrynew's agency. Bhasin was forced into less lucrative work with a competitor of Can-Am.

Bhasin sued Can-Am, inter alia, for breach of contract among other causes of action and by way of remedy sought damages including for loss of income and loss of the value of his business. $^{20}$

\section{B. Legal ANALYSIS}

\section{TRIAL LEVEL}

The trial judge implied a term of good faith in the contract between Bhasin and Can-Am - either by law or based on the parties' intent. Accordingly, the non-renewal clause recounted above had to be exercised pursuant to that standard, which is to say, fairly. ${ }^{21}$ The Court went on to conclude that the entire agreement clause — which stated that " $[\mathrm{t}] \mathrm{his}$ Agreement expresses the entire and final agreement between the parties hereto and supersedes all previous agreements between the parties. There are no representations, warranties, terms, conditions or collateral agreements, express, implied or statutory, other than expressly set out in this Agreement",22 — had no impact because: (1) Can-Am exercised its termination power "unfairly or abusively;" 23 (2) Bhasin was "not a sophisticated party relative to [Can-Am];" $" 24$ and (3) it would be unjust and inequitable to allow Can-Am to so rely. ${ }^{25}$ In response to a challenge based on the parol evidence rule, the trial judge followed a contextual approach to contractual interpretation, citing Steven Waddams' assessment that "words do not have immutable or absolute meanings; they take their meaning from their context." $" 26$

The trial judge went on to find that the good faith term was breached on multiple occasions by Can-Am. Most seriously, it acted "dishonestly" because, for example, it did not "explain" to Bhasin that a merger decision had already been made and was final. ${ }^{27}$ This, in turn, prevented Bhasin from governing himself accordingly "so as to retain the value in his agency throughout the process. Bhasin did not realize he was being pushed out until it was

Bhasin v Hrynew, 2011 ABQB 637, [2012] 9 WWR 728 at paras 12, 34 [Bhasin QB].

Ibid at para 104.

Ibid at para 110.

Ibid at para 118. The trial judge found that Can-Am exercised its discretion not to renew in bad faith, at paras $520-21$.

Ibid at para 115 .

Ibid at paras 117-18. See also paras 246-47.

Ibid at para 122, citing SM Waddams, The Law of Contracts, 4th ed (Aurora: Canada Law Book, 1999) at 232 .

Bhasin QB, ibid at para 258. See also paras 246-47. 
too late. ${ }^{28}$ And, beyond this, Can-Am breached an implied term of good faith by using the non-renewal clause as a way to force an unwanted merger. ${ }^{29}$

The trial judge awarded damages, inter alia, for loss of income and business in the sum of $\$ 380,597 .^{30}$

\section{APPELLATE LEVEL}

The appellate court made remarkably short work of reversing the trial judge's lengthy decision in its entirety. The Alberta Court of Appeal found that there was no duty of good faith performance engaged by the contract because: (1) a court cannot imply a term that conflicts with an express term; (2) establishing any such a term involved violating the parol evidence rule; and (3) the contract was governed by an entire agreement clause. ${ }^{31}$ Beyond this, the trial judge's view that notice could only be given for good faith reasons was untenable: such a conclusion "flatly" contradicted the wording of the renewal clause, ${ }^{32}$ and created a potentially perpetual contract.

\section{SuPREME COURT OF CANADA LEVEL}

The Supreme Court of Canada ruled in favour of Bhasin but not on the basis found by the trial judge. Justice Cromwell was unwilling to imply a term of good faith for a number of reasons. First, the association between Can-Am and Bhasin fell outside of existing situations or relationships (such as franchise or employment) ${ }^{33}$ where good faith has a presence. ${ }^{34}$ Any ruling that the exercise of non-renewal power required good faith "would constitute a significant expansion of the decided cases under that type of situation." 35 As well, and as noted by the Court of Appeal, implying a term of good faith would contravene the entire agreement clause. ${ }^{36}$ So instead, the Supreme Court took a step back and assessed the problem from a more foundational perspective.

As noted in the introduction to this article, the Supreme Court determined that there is a common law principle of "good faith contractual performance" and that one of its emanations is that there is "a common law duty which applies to all contracts to act honestly in the performance of contractual obligations." ${ }^{37}$ The Court was bolstered in creating this new duty of honesty because it "accords with the reasonable expectations of commercial parties" and "is sufficiently precise that it will enhance rather than detract from commercial certainty." 38

Ibid at para 258 .

Ibid at para 261 .

Ibid at para 527.

Bhasin v Hrynew, 2013 ABCA 98, 362 DLR (4th) 18 at paras 29-30 [Bhasin CA].

Ibid at para 33.

Bhasin SCC, supra note 1 at para 72.

Ibid at para 54 (good faith in employment contracts); para 55 (good faith in insurance contracts); and para 56 (good faith in tendering contracts).

Ibid at para 72 .

Ibid (in agreement with the Alberta Court of Appeal on this point).

Ibid at para 33.

Ibid at para 34. 
As Justice Cromwell notes, the "modest, incremental step" 39 represented by the new duty of honesty

means simply that parties must not lie or otherwise knowingly mislead each other about matters directly linked to the performance of the contract. This does not impose a duty of loyalty or of disclosure or require a party to forego advantages flowing from the contract; it is a simple requirement not to lie or mislead the other party about one's contractual performance. ${ }^{40}$

Justice Cromwell goes on to observe:

The duty of honest performance ... should not be confused with a duty of disclosure or of fiduciary loyalty. A party to a contract has no general duty to subordinate his or her interest to that of the other party. However, contracting parties must be able to rely on a minimum standard of honesty from their contracting partner in relation to performing the contract as a reassurance that if the contract does not work out, they will have a fair opportunity to protect their interests. That said, a dealership agreement is not a contract of utmost good faith (uberrimae fidei) such as an insurance contract, which among other things obliges the parties to disclose material facts. But a clear distinction can be drawn between a failure to disclose a material fact, even a firm intention to end the contractual arrangement, and active dishonesty. ${ }^{41}$

The Supreme Court of Canada was clear that Can-Am did not have a duty to disclose to Bhasin its intention not to renew but avoided a conclusion on whether Can-Am was in breach for having forced a merger of Bhasin's agency with that of Hrynew, his in-house competitor. $^{42}$ It simply agreed with the Alberta Court of Appeal's reliance on Hamilton $v$. Open Window Bakery Ltd. ${ }^{43}$ stating that any potential liability on Can-Am in a forced merger context "would still have to be measured by reference to the least onerous means of performance [by the defendant], which in this case would have meant simply not renewing the contract." 44 In such circumstances, no damages would flow. ${ }^{45}$ According to the Court, where Can-Am went wrong, however - and this fortunately for Bhasin's cause of action - was in dissembling on other fronts in ways that the trial judge directly linked to Bhasin's ultimate loss of his agency. Building on this foundation, the Supreme Court ruled that CanAm was in breach of the new duty of honesty in relation to its exercise of the non-renewal clause. ${ }^{46}$ Examples of dishonesty include: sending an organizational chart to the Alberta Securities Commission showing a merger of Bhasin's agency with that of Hrynew though Bhasin was unaware of such a proposal; $; 7$ "equivocating" and not responding truthfully when Bhasin finally asked about the merger; ${ }^{48}$ misrepresenting that Hrynew's role to audit Bhasin's agency was because the Securities Commission had rejected its efforts to put a third party

\footnotetext{
$\begin{array}{ll}39 & \text { Ibid at para } 73 . \\ 40 & \text { Ibid. }\end{array}$

$41 \quad$ Ibid at para 86 [citations omitted]. See also Infinity $v$ Wega, 2015 ONSC 607, 2015 ONSC 607 (CanLII) at $\mathrm{n} 12$, citing Bhasin SCC, supra note 1 at para 73 for the proposition that the duty of honesty does not impose a disclosure duty, at $\mathrm{n} 12$ of the decision.

$42 \quad$ Bhasin SCC, ibid at para 90.

2004 SCC 9, [2004] 1 SCR 303.

Bhasin SCC, supra note 1 at para 90.

Ibid.

Ibid at para 103 .

Ibid at para 99. This assessment of liability may trench on the statement in Bhasin SCC that the duty of honesty does not import a disclosure duty along with it. Ibid at para 100 .
} 
in place when this was not in fact the case $;{ }^{49}$ and representing that Hrynew would be bound by duties of confidentiality when in fact he was not. ${ }^{50}$ Some of this misconduct as found by the trial judge may well have been tortious (though no tort of fraud or negligence against Can-Am was referred to or found by the trial judge) but, at minimum, the conduct violated the new duty of honesty.

Indeed, and based on findings of fact by the trial judge, the Supreme Court of Canada concluded that had Can-Am been honest in contractual performance, Bhasin would have seen the writing on the wall, governed himself accordingly, ${ }^{51}$ and sought to sell or otherwise monetize his agency before Can-Am triggered its decision not to renew. Relying entirely on the trial judge's quantification of damages, the Supreme Court therefore awarded judgment to Bhasin in the amount of $\$ 87,000$ (plus interest and costs) as representing the value of Bhasin's agency at the time of non-renewal. ${ }^{52}$ In short, the judicial conclusion appears to be this: if Can-Am had dealt with Bhasin honestly on all fronts (though without requiring it to disclose its intention not to renew), Bhasin would have realized much sooner that his relationship with Can-Am was in tremendous jeopardy and reaching a breaking point. $\mathrm{He}$ therefore could have taken proactive steps to protect his business, ${ }^{53}$ instead of seeing it "in effect, expropriated and turned over to Mr. Hrynew." ${ }^{54}$

Though the Supreme Court of Canada expressly disclaimed a disclosure duty in Bhasin, there can be no doubt that a duty to disclose can be an incident of the good faith principle, depending on the facts. For example, in the post-Bhasin decision of 1250264 Ontario Inc. v. Pet Valu Canada Ltd ${ }^{55}$ Justice Belobaba observed in the context of the franchises under the Arthur Wishart Act that "there can indeed be situations where fair dealing requires that the franchisor tell the franchisee the truth about an important and material fact - particularly

Ibid at para 101 .

Ibid.

Ibid at para 109 .

Ibid at para 110. It is worth noting that Bhasin's options were limited as to what he could have done to preserve the value of his agency had he known Can-Am's true intentions. In short, he was obligated to deal with Can-Am in such a sale. According to Bhasin QB, supra note 20 at para 451:

In my discussion on the good faith term implied in the agreement, I noted that one reason for implying that term was that the agency was really a stream of income and that the tight controls placed on the agency (and the Enrollment Director) would make that agency less marketable. It is true, that Bhasin could have merged with another agency in Alberta and maybe sold, with the approval of [Can-Am], his agency to someone who could take advantage of that community. For reasons set out earlier, I find that it was difficult for an agency to sell to an outside third party and was difficult for an agency to retain its sales representatives even when that agency went to work for another financial company. [Can-Am] could but did not always approve mergers.

It is also the case that the trial judge, in assessing quantum, applied a "marketability" factor of 35 percent (ibid at para 452), and a discount rate of 20 percent (para 446).

53 According to Bolieiro, supra note 14 at 29:

One final comment to all litigators placing this new arrow in their quivers: remember, you still have to prove damages flowing from a bad faith performance of the contract. Justice Cromwell was clear that the only reason he could award any damages to Bhasin was because the trial judge specifically found that, but for Can-Am's dishonesty, Bhasin could have acted "so as to retain the value in his agency". In other words, Can-Am's dishonesty caused Bhasin to alter his position in a way that ultimately led to the loss of his business.

Perhaps if Bhasin had known earlier that Can-Am was trying to push him out, he could have taken better steps to convince his sales agents to stay with him rather than go with Hrynew. While the court was not too preoccupied with what exactly those steps were, the same cannot be said for our lower courts [footnotes omitted]. 
if the opposite was stated in the disclosure document and franchise agreement." ${ }^{, 56}$ As Justice Belobaba continues:

[W]hile it is true that the Supreme Court in Bhasin suggested that the common law duty of honesty in the performance of contractual agreements "does not impose a duty ... of disclosure" and that "[t]he duty of honest performance ... should not be confused with a duty of disclosure" one must remember that the Court was making this comment in the context of good faith in the common law and was not dealing with franchise relationships and the "special considerations" that arise under the statutory prescription set out in s. 3 of the Act. $^{57}$

Justice Belobaba's assessment that there can be a duty to disclose is certainly applicable to insurance contracts ${ }^{58}$ and, presumably, franchise contracts governed by the common law alone, ${ }^{59}$ to name two more examples.

It is also the case that a duty to disclose might be an incident of good faith in an employment contract, again depending on the facts. In a post-Bhasin decision, for example, the Kitchener Small Claims Court in Bray v. Ontario College of Massage and Hydrotherapy ${ }^{60}$ ruled that the defendant-employer's failure to disclose a complaint made against the plaintiff-employee was a breach of good faith performance. According to the Court:

I find that the subject-matter of the complaint could not reasonably have been viewed by the employer as proved or true facts based on the information then within its possession. I find that the failure to disclose this matter to [the plaintiff-employee], involving as it did a question of her honesty, and failing to give her an opportunity to respond, was a violation of the duty of good faith performance of a contract: Bhasin $v$. Hrynew, [2014] S.C.C. 71. ${ }^{61}$

The Court in Bray went on to take the exceptional step of awarding punitive damages. ${ }^{62}$

Ibid at para 58. This assessment also resonates in a non-franchise scenario: see e.g. Kerr $v$ Danier Leather Inc (2001), 19 BLR (3d) 254 (Ont Sup Ct J) (recertification application in the context of class action for breach of disclosure obligations under securities legislation: "Where a statement is true when made but subsequent facts make it untrue to the knowledge of the representor, failure to disclose the subsequent change will result in an actionable misrepresentation" at para 32).

Pet Valu Canada, ibid at para 58, citing Bhasin SCC, supra note 1 at paras 74, 86. It is also interesting to note that the Supreme Court of Canada in Bhasin heavily relied on an article published by Justice Belobaba prior to his judicial appointment. See Bhasin SCC, ibid at paras 36, 42, 43, 59, 73, 89. In Bhasin SCC, ibid at para 86, Justice Cromwell acknowledges that parties to an insurance contract have an obligation to disclose material facts, pursuant to Whiten v Pilot Insurance Co, 2002 SCC 18, [2002] 1 SCR 595 [Whiten].

$59 \quad$ See e.g. Machias v Mr Submarine Ltd (2002), 24 BLR (3d) 228 (Ont Sup Ct J) at para 112: Ontario's franchise legislation was intended to codify the common law requirement of good faith that attaches to the franchise contract. Disclosure duties are also an incident of good faith (at para 120). Bray v Canadian College of Massage and Hydrotherapy, 2015 CanLII 3452, [2015] OJ No 465 (QL) (Supt Ct (Sm Cl Div)) [Bray].

$61 \quad$ Ibid at para 76. For a pre-Bhasin case where the employee's failure to disclose led to his dismissal for cause, see Ernst v Destiny Software Productions Inc, 2012 BCSC 542, 2012 BCSC 542 (CanLII). In this case, the employee, Ernst (hired as a senior executive for the defendant) moved to Mexico without disclosing the move first or seeking permission. When Ernst finally told his employer that he was now living in Mexico, he was told the move was unacceptable. Ernst was eventually terminated. The Court agreed that just cause included Ernst's unilateral decision to relocate to Mexico (at para 137). Bray, ibid at para 72 . 
The Supreme Court of Canada in Bhasin states clearly that the duty of honesty is not a term and therefore it "operates irrespective of the intentions of the parties." ${ }^{\circ 3}$ And while the Court concluded that such a duty might be subject to qualification or modification in the right case, this did not occur in the contract at bar. As the Court states, such an effort would have to be express and that the generally worded entire agreement clause "does not indicate any intention of the parties to depart from the basic tenets of honest performance." of contractually qualifying the duty of honesty is revisited in Parts IV and V of this article.

Justice Cromwell generally refers to the new Bhasin duty as a duty of honesty but he also states that good faith calls for "a highly context-specific understanding of what honesty and reasonableness in performance require." ${ }^{65}$ For example, the principle of good faith would presumably operate differently in the context of a relational contract as opposed to a "more transactional exchange." ${ }^{\prime 66}$ In this way, Justice Cromwell signals that the duty of honesty is open to a higher standard of contractual performance - that of reasonableness - in some other context and on some other set of facts. ${ }^{67}$ In short, Justice Cromwell notes that '[i]n many of its manifestations, good faith requires more than honesty on the part of a contracting party" ${ }^{98}$ and cites, as one example, the case of Dynamic Transport Ltd. v. O.K. Detailing Ltd. ${ }^{69}$ In that case, the Supreme Court of Canada held that a good faith obligation on the facts at bar required the defendant to take reasonable steps to secure planning permission. Planning permission was a condition precedent to the real estate contract going forward. ${ }^{70}$ There can be little doubt that reasonableness constrains contractual behaviour much more rigorously than any concept of honesty ever could.

It is also worth noting that while, presumably, a given breach of the duty of honesty may also constitute the tort of fraudulent misrepresentation, ${ }^{71}$ the two actions are not necessarily co-extensive. Indeed, Justice Cromwell notes two differences on this front: first, that the duty of honesty (unlike civil fraud) "does not require the defendant to intend that the false statement is to be relied on" and second, that "breach of it supports a claim for damages according to contractual rather than the tortious measure." 72 In short, lying and knowing misrepresentation would amount to a breach of the contractual duty even if the defendant did

Bhasin SCC, supra note 1 at para 74.

Ibid at para 78 .

Ibid at para 69 [emphasis added].

Ibid.

For example, Justice Cromwell did not offer a more expansive version of the duty because any broader duty would not assist Bhasin. As he notes, the contract was subject to a non-renewal clause, so requiring its good faith exercise would transform the contract into a contract of indefinite duration. According to Justice Cromwell, this "is the principle difficulty in the trial judge's reasoning because ... her decision turned a three year contract that was subject to an express provision relating to non-renewal into a contract of roughly nine years' duration" (ibid at para 90).

Ibid at para 89.

Dynamic Transport Ltd v OK Detailing Ltd, [1978] 2 SCR 1072.

Ibid at 1082-83, cited in Bhasin SCC, supra note 1 at para 89.

The ingredients for the tort of civil fraud and fraudulent misrepresentation have recently been stated by the Supreme Court of Canada in Bruno Appliance and Furniture, Inc v Hryniak, 2014 SCC 8, [2014] 1 SCR 126 [Bruno Appliance] as comprising four elements, at para 21:

(1) a false representation made by the defendant; (2) some level of knowledge of the falsehood

of the representation on the part of the defendant (whether through knowledge or recklessness);

(3) the false representation caused the plaintiff to act; and (4) the plaintiff's actions resulted in a loss.

Bhasin SCC, supra note 1 at para 88. Note, however, that the Supreme Court of Canada's articulation of the test for civil fraud in Bruno Appliance, ibid does not expressly break out as an ingredient that the defendant intended reliance on the false statement. 
not intend reliance. Beyond this, the Supreme Court of Canada seems to have suggested that equivocating can count as a form of dishonesty, which again sets a less onerous standard. That equivocations are potentially captured, may, in the words of John McCamus, "be a source of surprising applications of the new duty." ${ }^{, 73}$

While the line between dishonesty and fraud can be difficult to draw, the common law has traditionally enforced a distinction. For example, in the context of contract formation between private individuals pursuing an "as is" contract, the doctrine of caveat emptor puts the obligation on the buyer to ask, not on the seller to tell. As a general principle, therefore, when a seller remains silent and does not disclose to the purchaser an issue or difficulty that may negatively impact the value of the contract's subject matter, that failure may be considered dishonest in this sense of lacking in integrity but typically not fraudulent or otherwise actionable. ${ }^{74}$ But even with this distinction in mind, it also stands to reason that in a number of cases at least, the dishonest conduct complained of would sound in contract and in tort.

In the end, it would seem that the duty of honesty is very much a hybrid between a contractual term and a contractual doctrine. Like the doctrine of unconscionability, it operates independently of the parties' intentions and is therefore not excluded by operation of a "generically worded" entire agreement clause. ${ }^{75}$ Like a term, however, its violation sounds in contractual damages, ${ }^{76}$ and not the rescissionary measure one generally associates with violation of a contractual doctrine such as unconscionability. Like a term, the duty can likely be defined or relaxed ${ }^{77}$ as between the parties so as to respect freedom of contract but, like a doctrine, its "minimum core requirements" mandatorily govern the relationship between the parties. ${ }^{78}$

\section{Good Faith as an Organizing Principle}

The idea that contract law is governed by a general good faith principle can initially appear confusing as good faith in Canadian common law has been most overtly visible as a term - whether express or implied. But the actual process simply has one more step: it is from the principle of good faith that, as one example, the term of good faith emanates. As Justice Cromwell notes, an "organizing principle ... is not a free-standing rule but rather a standard that underpins and is manifested in more specific legal doctrines and may be given

73 John D McCamus, “The New General 'Principle' of Good Faith Performance and the New 'Rule' of Honesty in Performance in Canadian Contract Law" (2015) 32:2 J Contract L 103 at 114.

74 The term caveat emptor was discussed in the following terms in Rushak $v$ Henneken, [1986] BCJ No 3072 (QL) (BCSC) at para 173 [citations omitted], aff'd 1991 CanLII 178 (BCCA) as follows:

At a common law in the absence of a fiduciary or analogous relationship, there is not as between negotiating parties any duty of disclosure. Almost always the seller of an [sic] used car knows of its defects, or at least some of them, but he is not under any duty to disclose them to a potential buyer, unless there has been on his part active concealment, that is, he has done something to the car with intent to prevent the defect being discovered.... The common law rule is caveat emptor. The underlying philosophy of the law of contract is that "a party is expected to look out for himself, and make his own bargains. If he has done foolishly, this is his own fault and he is left to his own devices."

Bhasin SCC, supra note 1 at para 78.

One does not consider unconscionability to be a breach of contract though it is obviously actionable. As noted, the Court in Bhasin SCC, awarded damages (ibid at para 112).

Ibid at para 77 .

Ibid. 
different weight in different situations." ${ }^{, 79}$ This very much echoes the Supreme Court of Canada's assessment in 1981 in National Bank of Canada v. Soucisse ${ }^{80}$ that underlying the rules in the Civil Code of Lower Canada, is "the principle that agreements must be performed in good faith." ${ }^{\prime 81}$ The analogy is even stronger when one considers Justice Cromwell's point that judicial recognition of the good faith principle in Soucisse actually preceded inclusion of an express good faith duty in "the revisions leading up to the enactment of the Civil Code of Québec." ${ }^{82}$

The logic of Justice Cromwell's approach to good faith in common law Canada emerges as examples are multiplied. As Justice Cromwell observes, the general good faith principle provides the foundation for unconscionability, for example - which, after all, is based on fairness and a refusal by the judiciary to permit one party from taking undue advantage of the other. ${ }^{83}$ As another example, contractual interpretation uses good faith as a touchstone because "considerations of good faith" help give effect to the intention of the parties at time of contractual formation: parties "may generally be assumed to intend certain minimum standards of conduct." ${ }^{\text {" A }}$ As a third example, the law of implied terms (particularly those terms implied by operation of law) are in the words of the Supreme Court of Canada, used to redress "power imbalances in certain classes of contracts such as employment, landlordlessee, and insurance contracts." ${ }^{.85}$ And good faith obligations are regularly imposed by statute law. ${ }^{86}$

As already noted, claims of good faith will generally fail unless they fit within existing doctrines relating to "the types of situations and relationships in which the law requires, in certain respects, honest, candid, forthright or reasonable contractual performance." ${ }^{, 87}$ Significantly, the Court endorses McCamus's identification of three types of situations where good faith in contractual performance has been triggered: “(1) where the parties must cooperate in order to achieve the objects of the contract; (2) where one party exercises a discretionary power under the contract; and (3) where one party seeks to evade contractual duties." 88 so while at least somewhat confined, it is also the case that the list of good faith claims "is not closed" ${ }^{89}$ and what it requires is always context-specific. ${ }^{90}$

Ibid at para 64. Other organizing principles might include how certain kinds of contracts are to be interpreted. See e.g. Geoff Hall, Canadian Contractual Interpretation Law, 2nd ed (Markham: LexisNexis Canada, 2012) at 187, who quotes the following interpretational principle in relation to employment contracts based on Rasanen v Lisle-Metrix Ltd (2004), 33 CCEL (3d) 47 (Ont CA) at para 1: "the judicial interpretation of contracts between employers and employees must be informed by the power imbalance between the two and the importance of employment to an individual's dignity and sense of self-worth." This approach to interpretation acts as an emanation of the good faith principle identified in Bhasin SCC, ibid.

[1981] 2 SCR 339 [Soucisse].

Ibid at 356. For discussion, see Bolieiro, supra note 14 at 24.

Bhasin SCC, supra note 1 at para 85.

Ibid at para 43. See also Hon Mr Justice Steyn, "The Role of Good Faith and Fair Dealing in Contract Law: A Hair-Shirt Philosophy?” (1991) 6 Denning LJ 131 at 136.

Bhasin SCC, supra note 1 at para 45.

Ibid at para 44 .

Ibid at para 46.

Ibid at para 66. The Supreme Court of Canada in Potter v New Brunswick Legal Aid Services Commission, 2015 SCC 10, [2015] 1 SCR 500 at para 99 refers to this quotation in Bhasin with approval.

Ibid at para 47 [citation omitted].

Ibid at para 66.

Ibid at para 69. 
The good faith principle is not, however, according to Justice Cromwell, to be used "as a pretext for scrutinizing the motives of contracting parties." 91 The scope of this statement is unclear but it seems unlikely that it is offered as an invariable rule. Certainly, it would seem that on the facts of Bhasin, Can-Am's motive not to renew could not be scrutinized since, by operation of the contract, Can-Am (and Bhasin for that matter) was entirely entitled not to renew whether for good, bad, or indifferent reasons. Indeed, reading in a good faith requirement for non-renewal was, in the words of Justice Cromwell, "the principal difficulty in the trial judge's reasoning because, in the result, her decision turned a three year contract that was subject to an express provision relating to non-renewal into a contract of roughly nine years' duration." 92

From a broader perspective, however, it would also seem inevitable that motive would be relevant at times. In short, motive can count as helping to prove actionable bad faith. For example, in Gateway v. Arton Holdings ${ }^{93}$ — a case referenced in Bhasin on several occasions - Justice Kelly found that Arton/LeHave, the defendant, was in breach of good faith because it strategically refused to sublet a large portion of space it had been assigned in a mall owned by its competitor, the plaintiff Gateway. It seemed clear that Arton/LaHave preferred to pay the rent and keep the space dark than fill it with a tenant whose business activity might benefit Gateway. In assessing context and motive, Justice Kelly concluded as follows:

It would appear from all of the evidence that Arton/LaHave had two tenants ready and willing to occupy 15,000 to 20,000 square feet of the 60,000 square foot space ... but failed to capitalize on these opportunities. Arton/LaHave also was advised by Gateway that it had interested department store companies who would fill the space. However, it clearly had no interest in accepting a department store in the premises, principally because it would strengthen the Plaza [Gateway's mall] and make it a viable shopping center and a competitive force for the Bridgewater Mall [owned by Arton/LaHave]. I find that Arton/LaHave failed to make proper and reasonable efforts to discharge its obligations under the lease, including the obligation to honestly search out tenants to maintain the viability of the Plaza.... In addition, they acted in bad faith in failing to deal with the real prospects of K-Mart and Towers presented by Gateway. Gateway encouraged Arton/LaHave to enter into a lease with a department store tenant and gain any financial benefits that might flow from such a lease. Instead, Arton/LaHave rejected the prospect of certain tenancy from one of these prospects because it believed the resulting benefit to the Plaza would have a harmful effect on its own Bridgewater Mall. ${ }^{94}$

Examples could easily be multiplied as in the following three Supreme Court of Canada decisions. In Whiten, the insurer's bad faith allegation of arson was made with the motive of forcing the plaintiff into an unfair settlement for the loss of her house. ${ }^{95}$ In Tercon Contractors Ltd. v. British Columbia (Transportation and Highways), ${ }^{96}$ the province's obfuscation regarding the eligibility of the successful bidder was made with the motive to

Ibid at para 90. See also Bhasin CA, supra note 31 at para 32

Gateway Realty Ltd v Arton Holdings Ltd and LaHave Developments Ltd (1991), 106 NSR (2d) 180 (SC (TD)), aff'd on narrower grounds (1992), 112 NSR (2d) 180 (CA) [Gateway]. See also the analysis by Bolieiro, supra note 14 at 27.

Gateway, ibid at para 108 [emphasis added].

Whiten, supra note 58 at para 1.

2010 SCC 4, [2010] 1 SCR 69 [Tercon]. 
permit it to choose an ineligible bidder in breach of a duty of fairness. ${ }^{97}$ And in Mason $v$. Freedman, ${ }^{98}$ the vendor intentionally failed, in bad faith, to fulfill a condition precedent with the motive of scuttling the real estate deal in question. ${ }^{99}$ Analysis of motive not only explains the bad faith behaviour at bar, it also tends to prove it.

But with that said, it is also the case that the absence of a poor motive does not necessarily offer legal exoneration and appropriately so. In M.J.B. Enterprises Ltd. v. Defence Construction (1951) Ltd., ${ }^{100}$ the Supreme Court of Canada found the owner to be in breach of contract A for choosing a non-compliant bid. In so doing, it rejected the owner's plea that it had not breached any duty of fairness ${ }^{101}$ since it had only inadvertently selected a noncompliant bid. As the Supreme Court responds:

\footnotetext{
The respondent's argument of good faith in considering the Sorochan bid to be compliant is no defence to a claim for breach of contract: it amounts to an argument that, because it thought it had interpreted the contract properly, it cannot be in breach. Acting in good faith or thinking that one has interpreted the contract correctly are not valid defences to an action for breach of contract. ${ }^{102}$
}

There are many other emanations of good faith beyond those recited by the Supreme Court of Canada in the English and Canadian common law, including the non-enforcement of penalty clauses, ${ }^{103}$ and the duty to mitigate as well as rules relating to: good faith in contractual negotiation; 104 "snapping up" an offer which the offeree knows has been made in error; ${ }^{105}$ the provision of relief against forfeiture; ${ }^{106}$ as well as relaxation of the third party privity bar in London Drugs Ltd. v. Kuehne \& Nagel International Ltd. ${ }^{107}$ Consider, as a final example, the law of estoppel which, according to the High Court of Australia, is founded on notions of "good conscience and fair dealing." 108 In short, the principle of good faith provides the context not just for finding solutions to new problems but for explaining old answers to old problems as well.

Ibid at paras $40,58-59$

Mason v Freedman, [1958] SCR 483.

Ibid at 487, and referenced with approval in Bhasin SCC, supra note 1 at para 51.

[1999] 1 SCR 619 [MJB Enterprises].

Ibid at para 43. Note that Shannon O'Byrne has argued elsewhere that the duty of fairness and the duty of good faith in a tendering context are largely co-extensive. See Shannon Kathleen O'Byrne, "The Implied Term of Good Faith and Fair Dealing: Recent Developments" (2007) 86:2 Can Bar Rev 193 at 231-32.

MJB Enterprises, ibid at para 54. See also the civil law analysis offered in Pierre-Gabriel Jobin \& Nathalie Vézina, Les Obligations, 7th ed (Cowansville: Thomson Reuters, 2013) at 221, cited and translated in Bhasin SCC, supra note 1 at para 83:

[A] person can be in good faith (in the subjective sense), that is, act without malicious intent or without knowledge of certain facts, yet his or her conduct may nevertheless be contrary to the requirements of good faith in that it violates objective standards of conduct that are generally accepted in society.

Lord Bingham in Interfoto Picture Library Ltd v Stiletto Visual Programmes Ltd (1987), 1 QB 433 (CA) (in relation to good faith, the English common law "has, characteristically, committed itself to no such overriding principle but has developed piecemeal solutions in response to demonstrated problems of unfairness.... [This includes] by treating as irrecoverable what purport to be agreed estimates of damage but are in truth a disguised penalty for breach, and in many other ways" at 439).

This area of law is addressed in detail in 0856464 BC Ltd v TimberWest Forest Corp, 2014 BCSC 2433, [2014] BCJ No 3170 (QL) at para 157ff. This case relies on Bhasin SCC, supra note 1, in its analysis. Steyn, supra note 83 at $136-37$.

Ibid at 136.

[1992] 3 SCR 299. We are grateful to Christopher Felling (third year JD student at the Faculty of Law, University of Alberta) for this observation.

Waltons Stores (Interstate) Ltd v Maher (1988), 76 ALR 513 at 546 (HC), Deane JA. 
A very helpful account of what the Court means by the good faith principle is offered by Bolieiro. Relying on Bhasin's analysis of Ronald Dworkin's distinction between rules and principles, Bolieiro observes that a principle (like the principle of good faith) does not dictate results. Rather, it justifies results. ${ }^{109}$ As she notes, principles "are weighed against other principles to help judges come to the right result: the result that does justice between the parties in each case." ${ }^{\prime 10}$ As examples, she offers the following: "competent parties should be free to contract; courts should encourage commercial certainty; and parties generally must perform their contractual duties in good faith."111

Again relying on Dworkin, Bolieiro contrasts principles with rules. Rules do dictate results and "are applied on an all-or-nothing basis. If a rule's requirements are met, it will command a specific result." 112 She notes the following examples of rules: "words outside the written contract that vary or contradict its terms cannot be used to determine the contract's meaning; and a party cannot lie or knowingly mislead another party about matters linked to the performance of the contract." 113

Justice Cromwell's approach is also reminiscent of Chief Justice McLachlin's discussion in her article "The Evolution of the Law of Private Obligations" " wherein she distinguishes between two approaches to the development of law and precedent - formalism and universalism: "Universalism seeks the broad, general principles underlying the imposition of responsibility and the corresponding rights of recovery. It seeks to rationalize both the disparate branches of the law and the doctrine within those branches. Principle is prime; broad considerations of policy are foremost." ${ }^{115}$ The advantages of universalism include that it permits the law to develop rationally and coherently ${ }^{116}$ and allows judges to "adjust the law to avoid an unjust result in particular cases" $" 117$ as well as permits them to "set the law on a particular course of policy." "118 By way of contrast, formalism, in Chief Justice McLachlin's estimation, is more concerned about "rules, precedent and categories" with legal change only happening in "well defined and circumscribed 'new' situations." "In short, "[t]he primary task is to discover the correct rule and apply it" whether the formalist is happy about the result it requires or not. ${ }^{120}$ Its advantages are that it is "clear and predictable"121 and second, it protects against "judicially imposed changes that may have unforeseen negative consequences." 122

Bolieiro, supra note 14 at 24. See Bhasin SCC, supra note 1 at para 64 for reference to RM Dworkin, "Is Law a System of Rules?" in RM Dworkin, ed, The Philosophy of Law (Oxford: Oxford University Press, 1977) 38 at 47.

Bolieiro, ibid [emphasis added].

Ibid.

Ibid.

Ibid.

Beverley McLachlin, "The Evolution of the Law of Private Obligation: The Influence of Justice La Forest" in Rebecca Johnson et al, eds, Gérard V. La Forest at the Supreme Court of Canada 1985-1997 (Winnipeg: Canadian Legal History Project, 2000) 21. Ibid at 22 .

Ibid at 23 .

Ibid.

Ibid.

Ibid at 22

Ibid.

Ibid.

Ibid. 
It seems that Bhasin - and Supreme Court of Canada jurisprudence over the last several decades ${ }^{123}$ - largely falls within a universalist camp. The language of Bhasin analysed throughout this article very clearly resonates with the way in which Chief Justice McLachlin describes the aspirations of a universalist approach. Justice Cromwell's good faith principle seeks to rationalize, unite, and organize the fractured state of good faith in common law Canada. And through this rationalization, it is intended that the principle will foster a more consistent, open, and sustainable body of law governing contractual performance and beyond.

\section{RELAXING THE REQUIREMENTS OF THE BHASIN DUTY OF HONESTY}

This part will explore the interpretational matter of modifying or otherwise reducing the new duty of honesty, first from the perspective of Canadian law and then, in Part V, by considering how the UCC and related American contract law jurisprudence would approach the matter. As Justice Cromwell observes, "[t]he precise content of honest performance will vary with context and the parties should be free in some contexts to relax the requirements of the doctrine so long as they respect its minimum core requirements" ${ }^{\prime 24}$ and goes on to state that

the approach I outline here is similar in principle to that in s. 1-302(b) of the U.C.C. (2012):

The obligations of good faith, diligence, reasonableness and care ... may not be disclaimed by agreement. The parties, by agreement, may determine the standards by which the performance of those obligations is to be measured if those standards are not manifestly unreasonable. ${ }^{125}$

In this way, Justice Cromwell insists on the "the freedom of contracting parties to pursue their individual self-interest" ${ }^{\prime 26}$ while at the same time demanding a minimum or rock-bottom standard of honesty in contractual arrangements. ${ }^{127}$ As previously noted, the Court held that the generically-worded "entire agreement clause" in Bhasin did not have the effect of ousting the duty of honesty and that such ousting would have to be express. ${ }^{128}$

Justice Cromwell's brief assessment of relaxing the duty of honesty by contract itself engages the topic of exclusion clauses, broadly construed, and their enforceability. If an exclusion clause expressly did purport to relax the Bhasin duty, against what standard would its enforceability be measured? The Supreme Court of Canada decision in $\operatorname{Tercon}^{129}$ is the leading authority on point, setting out a "three issue framework" for assessing the

\footnotetext{
123 Ibid at 23.

124 Bhasin SCC, supra note 1 at para 77 [emphasis added].

125 Ibid, citing UCC § 1-302(b) (2001).

126 Bhasin SCC, ibid at para 70.

127 Ibid at para 77. As Angela Swan notes, the duty of honesty exists "because the parties are in a relation where the organizing principle applies, not because they have an agreement with particular terms." See Angela Swan, "The Obligation to Perform in Good Faith: Comment on Bhasin v Hrynew" (2015) 56:3 CBLJ 395 at 402. 
enforceability of an exclusion clause. Writing for a unanimous court at this particular juncture, ${ }^{130}$ Justice Binnie stated as follows:

The first issue, of course, is whether as a matter of interpretation the exclusion clause even applies to the circumstances established in evidence. This will depend on the Court's assessment of the intention of the parties as expressed in the contract. If the exclusion clause does not apply, there is obviously no need to proceed further with this analysis. If the exclusion clause applies, the second issue is whether the exclusion clause was unconscionable at the time the contract was made, "as might arise from situations of unequal bargaining power between the parties." This second issue has to do with contract formation, not breach.

If the exclusion clause is held to be valid and applicable, the Court may undertake a third enquiry, namely whether the Court should nevertheless refuse to enforce the valid exclusion clause because of the existence of an overriding public policy, proof of which lies on the party seeking to avoid enforcement of the clause, that outweighs the very strong public interest in the enforcement of contracts. ${ }^{131}$

Unconscionability under the second issue of this framework has been understood by subsequent courts to trigger the traditional proof of procedural inequality and substantive unfairness, though how the actual test is articulated does vary across jurisdictions. ${ }^{132}$ As noted by the British Columbia Court of Appeal in Roy v. 121393 Ontario Inc., however, "[i]t is apparent from the comments of Binnie J. [under issue 2] ... that he was not intending to signal a departure from the usual test for unconscionability." ${ }^{\prime 133}$ It is also clear that unconscionability assesses matters at the time of formation of the contract.

Overriding public policy takes into account the circumstances at time of breach such that the exclusion clause is rendered unenforceable. ${ }^{134}$ For Justice Binnie, the plaintiff must be able to "point to some paramount consideration of public policy sufficient to override the public interest in freedom of contract and defeat what would otherwise be the contractual rights of the parties." 135 To amplify discussion of this point, Justice Binnie quotes Waddams as follows: "it is surely inevitable that a court must reserve the ultimate power to decide when the values favouring enforceability are outweighed by values that society holds to be more important." "136 For Justice Binnie, the defendant's conduct "need not rise to the level of criminality or fraud to justify a finding of abuse" ${ }^{137}$ under the third issue, though Justice

The Court in Tercon, ibid, split (5:4) on application of the framework to the case at bar. The majority (LeBel, Deschamps, Fish, Charron, and Cromwell JJ) ruled that the exclusion clause did not, by its simple wording, prohibit a lawsuit by the disappointed tenderer, Tercon Contractors Ltd. The minority (McLachlin CJC, Binnie, Abella, and Rothstein JJ) found that it did.

131 Ibid at paras 122-23 [citations omitted] [emphasis added]. For a discussion of the origins of issue 2 and 3 of the framework, see Shannon O'Byrne, "Assessing Exclusion Clauses: The Supreme Court of Canada's Three Issue Framework in Tercon Contractors Ltd v British Columbia (Transportation and Highways)" (2012) 35:1 Dal LJ 215 [O’Byrne, "Assessing Exclusion Clauses"].

132 For discussion of the test for unconscionability, see O'Byrne,"Assessing Exclusion Clauses," ibid, nn $105-108$ and accompanying text.

1332011 BCCA 500, 345 DLR (4th) 323 at para 30.

As Justice Binnie states in Tercon, supra note 96 at para 117: "I accept that there may be well-accepted public policy considerations that relate directly to the nature of the breach, and thus trigger the court's narrow jurisdiction to give relief against an exclusion clause" [emphasis in original]. Ibid at para 82 . 
Binnie's examples tend very clearly in that direction, including vendors intentionally selling toxic milk for consumption by babies. ${ }^{138}$

Most certainly, under Tercon or any other approach, an exclusion of liability clause cannot successfully exonerate for fraud. As Justice Perrell of the Ontario Superior Court stated in 2014: "There is an established principle that a disclaimer or exculpatory clause will not immunize a tortfeasor from an award of damages for committing the tort of fraudulent misrepresentation. There is ample authority for the proposition that 'fraud vitiates every contract and every clause in it." "139 Though Justice Binnie's assessment that the impeached conduct need not amount to fraud or a crime, ${ }^{140}$ for non-enforcement of an exclusion of liability clause, it would seem inevitable that criminality or fraud would, indeed, always hit the mark of non-enforceability.

While attempting to contract out of fraud is not enforceable, what about a clause permitting one party to functionally defame the other with impunity? This is a germane enquiry since defamation, in Lewis Klar's words, concerns an extreme form of dishonesty, namely, wrongly holding someone else up to "contempt, hatred, scorn or ridicule, or which cause a person to be discredited, detested, shunned and avoided." 141 An exclusion clause permitting defamation may seem unthinkable and it almost certainly would be unenforceable in an employment contract given the factual matrix involving employee vulnerability (discussed later in this Part). But it has been found to be perfectly fine in an arms-length, commercial context. In response to complaints by a former Dragons' Den contestant about how he was depicted on the popular television show (including that he was defamed), the Ontario Court of Appeal stated in MHR Board Game Design Inc. v. Canadian Broadcasting Corp. as follows: "The release [signed by the plaintiff] gave the $\mathrm{CBC}$ sole discretion to edit the recording as it saw fit and to portray a factual, fictional or defamatory image of the appellants. Under these circumstances, there could be no contractual duty to edit the broadcast in a favourable manner as alleged."142 The Court of Appeal left undisturbed the

\section{Ibid.}

DLG \& Associates Ltd v Minto Properties Inc, 2014 ONSC 7287, 2014 ONSC 7287 (CanLII) at para 69 [citations omitted].

Tercon, supra note 96 at para 118.

Lewis Klar, Tort Law, 5th ed (Toronto: Thomson Reuters, 2012) at 785.

2013 ONCA 728, 20 BLR (5th) 93 at para 6, leave to appeal to the SCC refused, 35752 (22 May 2014) [MHR Board Game Design]. The release executed by Ribeiro before the audition stated as follows, at para 4:

9. I understand that I may reveal, and other parties may reveal, information about me that is of a personal, private, embarrassing or unfavourable nature, which information may be factual and/or fictional. I further understand that my appearance, depiction and/or portrayal in the Program may be disparaging, defamatory, embarrassing or of an otherwise unfavourable nature which may expose me to public ridicule, humiliation or condemnation. I acknowledge and agree that Producer shall have the right to (a) include any or all such information and any or all such appearances, depictions or portrayals in the Program as edited by Producer in its sole discretion, and (b) to broadcast and otherwise exploit the Program containing any or all such information and any or all such appearances, depictions or portrayals in any manner whatsoever in any and all media now known or hereafter devised, or for any other purpose, throughout the universe in perpetuity.

27. I hereby irrevocably agree that I will not sue or claim against any of the other participants in the Program or the Released Parties for any damage, loss or harm to me or my property howsoever caused, resulting or arising out of or in connection with ... participation and appearance in or elimination from the Program or activities associated with the Program. I acknowledge that there is a possibility that after my execution of this Consent and Release, I will discover facts or incur or suffer claims where were unknown or unsuspected at the time this Consent and Release was executed and which, if known by me at that time, may have materially affected my decision to execute this Consent and Release. I acknowledge and agree that by reason of this Consent and 
trial judge's assessment that the release was not unconscionable or contrary to public policy. As the trial judge stated, the plaintiff failed to demonstrate "how the enforcement of the contract would be contrary to public policy. He acknowledges that the Dragons Den program is oriented to entertainment, not public education. There is no evidence supporting an allegation of public harm." 143

By way of contrast, there is a strong argument that a clause functionally excluding employer liability for defamation or otherwise permitting the employee to be treated with derision or dishonesty would not be enforceable - at least not in the ordinary case. As is well known, the factual matrix of the traditional employment relationship often signals vulnerability. Work is fundamental to an individual's identity according to the Supreme Court of Canada in Machtinger v. HOJ Industries Ltd. ${ }^{144}$ and, assessing this kind of pronouncement, the Ontario Court of Appeal in Ceccol v. Ontario Gymnastic Federation observed that: "the Supreme Court of Canada has discussed, often with genuine eloquence, the role work plays in a person's life, the imbalance in many employee-employee relationships and the desirability of interpreting legislation and the common law to provide a measure of protection to vulnerable employees." "145 Indeed, as Justice Braidwood states in Deildal v. Tod Mountain Ltd.:

The contract under consideration here is not a simple commercial exchange in the marketplace of goods and services. A contract of employment is typically of longer term and more personal in nature than most contracts, and involves greater mutual dependence and trust, with a correspondingly greater opportunity for harm or abuse. ${ }^{146}$

And finally, consider the Supreme Court of Canada's assessment in Wallace v. United Grain Growers Ltd.:

This power imbalance [between an employer and employee] is not limited to the employment contract itself. Rather, it informs virtually all facets of the employment relationship.... This unequal balance of power led the majority of the Court ... to describe employees as a vulnerable group in society. The vulnerability of employees is underscored by the level of importance which or society attaches to employment. ${ }^{147}$

The nature of the employment contract and how it is to be interpreted can be used as links to Tercon's public policy analysis. As the British Columbia Court of Appeal noted more generally in Niedermeyer v. Charlton in 2014: "Binnie J. made clear that the conduct resulting in a breach of contract 'need not rise to the level of criminality or fraud to justify a finding of abuse,", 148 and, later in the judgment that: "the Court recognizes in Tercon that

Release, and the release contained in the preceding paragraph, I am assuming any risk of such unknown facts and such unknown and unsuspected claims. MHR Board Game Design Inc v Canadian Broadcasting Corp, 2013 ONSC 4457, 18 BLR (5th) 108 at para 15 .

[1992] 1 SCR 986.

(2001), 204 DLR (4th) 688 (ONCA) at para 47 [citation omitted].

[1997] 6 WWR 239 (BCCA) at para 77.

[1997] 3 SCR 701 at paras 92-93 [citations omitted].

Niedermeyer $v$ Charlton, 2014 BCCA 165, 374 DLR (4th) 79 at para 77 [citations omitted], leave to appeal to SCC refused, 35960 (20 November 2014). 
the nature of the breach or the contract itself could give rise to a public policy interest capable of overriding freedom of contract." 149

Based on this kind of analysis, a court might well choose to distinguish an employment contract exclusion clause for defamation from the kind of contract and clause present in the Dragons Den case. As Justice Cromwell observed in Bhasin: "the general organizing principle of good faith would likely have different implications in the context of a long-term contract of mutual cooperation than it would in a more transactional exchange." ${ }^{" 150}$ In short, freedom to relax the duty of honesty may not be available in every case.

What about the facts of Bhasin? It will be recalled that in Bhasin, Can-Am was found to have lied, misrepresented, and equivocated on several occasions, including when Bhasin asked about the proposed merger with Mr. Hrynew. If Can-Am had simply refused to answer any such questions, it would likely have escaped liability but also likely tipped its hand to Bhasin that it was intending to merge agencies or not renew his contract with them. In short, saying nothing in response to a direct enquiry would be equivalent to an admission that a non-renewal or merger was on the horizon. But what would have happened in Bhasin if the contract in question had contained the following clause:

\footnotetext{
Neither party to this agreement shall be obliged to disclose their intentions with respect to the exercise or non-exercise of rights or the performance or non-performance of obligations under this contract, whether voluntarily or in response to inquiry by the opposite party. ${ }^{151}$
}

While the clause in question does not amount to a direct contracting out from or relaxation of the duty of honesty, it does seek to constrain the range of acceptable enquiries between the contractual parties in a way that is express and does not at least obviously trigger unconscionabilty or public policy concerns. Such a clause is by no means bullet proof because, for example, the line between lying and a failure to correct a known misapprehension is elusive. ${ }^{152}$ However, drafting around the duty of honesty through specificity stands a better chance of enforceability than a generic clause that impinges too far on the core content of the duty of honesty. The latter kind of clause is more likely to raise concerns under Tercon's second and third issues. And as Justice Cromwell observes, "[i]t will surely be rare that parties would wish to agree that they may be dishonest with each other in performing their contractual obligations."153

Ibid at para 79 [emphasis added]. This passage and the one referenced in note 148, ibid were also cited with approval by Roy v 1216393 Ontario Inc, 2014 BCCA 429, 378 DLR (4th) 702 at para 69.

150 Bhasin SCC, supra note 1 at para 69 [citations omitted].

151 We are indebted to Professor Tamara Buckwold for drafting this clause and sharing it with us. We note that this is not technically an exclusion of liability clause and the reach of Tercon in such circumstances is not settled. Whether Tercon only applies to exclusion of liability clauses or beyond remains somewhat uncertain and beyond the scope of this article to canvass. But in any event, as Professor Buckwold notes, the clause in question could be drafted as an exclusion clause as follows:

Neither party to this agreement shall incur liability on any grounds, whether in contract, tort or for

breach of any legal duty, for failure to disclose their intentions with respect to the exercise or non-

exercise of rights or the performance or non-performance of obligations under this contract,

whether voluntarily or in response to inquiry by the opposite party. 


\section{THE Obligation OF GoOd FAith UNDER AMERICAN CONTRACT LAW AND ITS RELAXATION}

Justice Cromwell notes that the Canadian common law approach to good faith performance has historically lacked "coherence" and is "out of step with the reasonable expectations of commercial parties, particularly those of at least two major trading partners," namely Quebec and the United States. ${ }^{154}$ Recognition in Bhasin of the principle of good faith and the duty of honesty goes some incremental distance in bridging this gap as well as helping to bring, in Justice Cromwell's words, "certainty and coherence"155 to the area. Additionally, Justice Cromwell finds an inspirational possibility in the UCC provision which permits parties to relax the good faith obligation which is otherwise a mandatory part of every contract under its umbrella. The objective of this Part of the article is to explore the UCC prospect raised by Justice Cromwell through a consideration of contractual good faith and how it can be limited by the parties' agreement pursuant to American law. This, in turn, sheds light on the extent to which the Bhasin duty of honesty can likewise be successfully reduced under the banner of freedom of contract.

\section{A. GoOd FAITH AND THE UCC}

The obligation of good faith in contracts in the American common law reaches at least as far back as the mid to late 19th century ${ }^{156}$ — well prior to its UCC promulgation in $1951 .{ }^{157}$ For example, Justice Cromwell in Bhasin references the well-known 1933 case of Kirke La Shelle Company Co. v. Paul Armstrong Co., in which the New York Court of Appeals stated that in every contract "there is an implied covenant that neither party shall do anything which will have the effect of destroying or injuring the right of the other party to receive the fruits of the contract, which means that in every contract there exists an implied covenant of good faith and fair dealing." 158 Building on such a foundation, both the UCC and the Restatement Second of Contracts incorporate good faith as a basic obligation under US contract law.

The UCC is a comprehensive model statute which seeks to advance legal harmonization in commercial transactions. Duke Law, on its Uniform Commercial Code website, succinctly explains that the UCC text and draft revisions are

written by experts in commercial law and submitted as drafts for approval to the National Conference of Commissioners on Uniform State Laws (referred to as the Uniform Law Commissioners), in collaboration with the American Law Institute. The Commissioners are all attorneys, qualified to practice law, including state and federal judges, legislators and law professors from throughout the United States and its territories. These quasi-public organizations meet and decide whether to endorse these drafts or to send them back to

\footnotetext{
$154 \quad$ Ibid at para 41.

155 Ibid at para 62

156 Harold Dubroff, "The Implied Covenant of Good Faith in Contract Interpretation and Gap-Filling: Reviling a Revered Relic” (2006) 80:2 St John's L Rev 559 at 559, 564.

157 Ibid at 559, n 2 (Dubroff notes that the UCC in its original version had three general sections concerning good faith).

158188 NE 163 at 167 (NYCA 1933) [Kirke La Shelle Company] [citations omitted], cited in Bhasin SCC, supra note 1 at para 85 .
} 
the experts for revision. The revision process may result in several different revisions of the original draft.

Once a draft is endorsed, the Uniform Law Commissioners recommend that the states adopt these rules. ${ }^{159}$

The UCC is "generally viewed as one of the most important developments in American Law," 160 with its application being limited to such areas as sales, leases, negotiable instruments, and secured transactions. ${ }^{161}$ It has been adopted in some form by all 50 states; a vast majority of states have also adopted the amendments concerning good faith discussed below. ${ }^{162}$

Section 1-304 of the UCC provides as follows: "Every contract or duty within [the Uniform Commercial Code] imposes an obligation of good faith in its performance and enforcement." 163 The pre-2001 version of Article 1 of the UCC defined good faith in a limited fashion, however, as "honesty in fact in the conduct or transaction concerned."164 Such a narrow, subjective approach to good faith (otherwise known as the "pure heart and the empty head" test ${ }^{165}$ ) was, in the words of Dubroff:

[P]robably the most controversial aspect of the original U.C.C.'s good faith provisions. The limitation was roundly criticized by commentators, and revised Article 1, adopted in 2001, expanded the general definition of good faith to require objective good faith (i.e., observance of reasonable commercial standards of fair dealing) was well as subjective good faith. ${ }^{166}$

Indeed, the 2001 amendment newly defined good faith as "honesty in fact and the observance of reasonable commercial standards of fair dealing." ${ }^{.167}$ With no express reference to criticism of the earlier definition, the Official Comments to the UCC simply explain that this amendment was propelled on the following basis: over time, the more expansive definition of good faith under Article 2 (governing the merchants' sales contracts) was brought by

Duke Law, Uniform Commercial Code (UCC) (July 2015), online: Duke Law <https://law.duke.edu/lib/ researchguides/ucc/>.

Ibid.

The complete list as transactions governed by the UCC is as follows: Sales (Amended Article 2); Leases (Amended Article 2A); Negotiable Instruments, previously known as Commercial Paper (Revised Article 3); Bank Deposits and Collections (Amended Article 4); Funds Transfers (Article 4A); Letters of Credit (Revised Article 5); Bulk Sales, previously known as Bulk Transfers (Revised Article 6); Documents of Title (Revised Article 7); Investment Securities (Revised Article 8); and Secured Transactions (Revised Article 9). See Uniform Law Commission, “Acts” (2015), online: Uniform Law Commission $<$ www.uniform lawcommission.com/Acts.aspx $>$. See Uniform Law Commission, ibid.

163 UCC § 1-304 (2001). The Official Comment to this section of the UCC confirms that good faith is a basic principle that runs throughout the Code. More specifically, the principle is that

in commercial transactions good faith is required in the performance and enforcement of all agreements or duties.... This section does not support an independent cause of action for failure to perform or enforce in good faith. Rather, this section means that a failure to perform or enforce, in good faith, a specific duty or obligation under the contract, constitutes a breach of that contract or makes unavailable, under the particular circumstances, a remedial right or power. This distinction makes it clear that the doctrine of good faith merely directs a court towards interpreting contracts within the commercial context in which they are created, performed, and enforced, and does not create a separate duty of fairness and reasonableness which can be independently breached.

American Law Institute, Uniform Commercial Code, 2014-2015 ed (Philadelphia: American Law Institute, 2014) at 58-59. UCC §1-201(19) (Pre-2001 Revision). Robert Braucher, "The Legislative History of the Uniform Commercial Code" (1958) 58:6 Colum L Rev 798 at 812. 
amendment into other Articles of the UCC. It therefore made sense, according to the Official Comments, "to move the broader definition of 'good faith' to Article 1,"168 an Article which contains general provisions "equally applicable to all subsequent Articles."169

Most significantly for current purposes, Article 1 of the UCC provides a way of limiting good faith in a contract, as follows:

\section{$\S 1$-302. VARIATION BY AGREEMENT}

(a) Except as otherwise provided in subsection (b) or elsewhere in [the UCC], the effect of provisions of [the UCC] may be varied by agreement.

(b) The obligations of good faith, diligence, reasonableness, and care prescribed by [the UCC] may not be disclaimed by agreement. The parties, by agreement, may determine the standards by which the performance of those obligations is to be measured if those standards are not manifestly unreasonable. Whenever [the UCC] requires an action to be taken within a reasonable time, a time that is not manifestly unreasonable may be fixed by agreement. ${ }^{170}$

\section{B. GoOd FAITH AND THE RESTATEMENT (SECOND) OF CONTRACTS}

The Restatement (Second) of Contracts is a non-binding legal treatise for common law (non-UCC) contracts, including employment contracts, service contracts, real estate contracts, and franchise contracts. As a Restatement, it offers "a synthesis of the evolving law in a specific subject that is cast in a form similar to legislative rules." 171 Published by the American Law Institute, the Restatement (Second) of Contracts is the work of some of the most renowned legal scholars in contract law. ${ }^{172}$ Like the UCC, the Restatement recognizes good faith, stating:

\section{$\S 205$ Duty of Good Faith and Fair Dealing}

Every contract imposes upon each party a duty of good faith and fair dealing in its performance and its enforcement.

Unlike the UCC, however, the Restatement makes no reference as to whether good faith can be disclaimed or not, an omission that E. Allan Farnsworth critiques in the following terms: "Even though the American Law Institute (ALI), in drafting the Restatement, had the ability

168 UCC § 1-201 cmt. (20) (2001).

Duke Law, supra note 159.

UCC § 1-302 (2001).

Geoffrey C Hazard Jr, “The American Law Institute is Alive and Well” (1998) 26:3 Hofstra L Rev 661 at 662 .

172 Reporters for the Restatement (Second) of Contracts are Robert Braucher, Associate Justice, Supreme Judicial Court of Massachusetts and the late E Allan Farnsworth, Columbia University School of Law. 
to include the prevailing view among American courts — of relevance here, that a disclaimer of the duty violates public policy — the ALI failed to do so." $" 173$

In the comments to $\S 205$, the authors of the Restatement refer to the UCC definition of good faith and add that:

[I]ts meaning varies somewhat with the context. Good faith performance or enforcement of a contract emphasizes faithfulness to an agreed common purpose and consistency with the justified expectations of the other party; it excludes a variety of types of conduct characterized as involving "bad faith" because they violate community standards of decency, fairness or reasonableness. ${ }^{174}$

The comment goes on to explain that:

Subterfuges and evasions violate the obligation of good faith in performance even though the actor believes his conduct to be justified. But the obligation goes further: bad faith may be overt or may consist of inaction, and fair dealing may require more than honesty. A complete catalogue of types of bad faith is impossible, but the following types are among those which have been recognized in judicial decisions: evasion of the spirit of the bargain, lack of diligence and slacking off, willful rendering of imperfect performance, abuse of a power to specify terms, and interference with or failure to cooperate in the other party's performance. ${ }^{175}$

\section{Defining the Obligation of Good Faith}

It is beyond the scope of this article to explore in any depth how good faith under the UCC and the Restatement has been understood — whether by judges or academics. It is nonetheless important to spend some time on the debate since understandings of good faith also impact on the reach of contracting out of such an obligation under $\S 1-302$ of the UCC.

For their part, legal scholars have offered a variety of approaches in their attempts to crystallize the obligation of good faith ${ }^{176}$ and a small sampling will be used to illustrate the point. According to Robert Summers, a specific definition of good faith is impossible and it is best defined as an "excluder."177 In this view, the absence of bad faith is good faith. Farnsworth takes a different tack, noting that:

Good faith performance has always required the cooperation of one party where it was necessary in order that the other might secure the expected benefits of the contract. And the standard for determining what cooperation was required has always been an objective standard, based on the decency, fairness or

E Allan Farnsworth, "Duties of Good Faith and Fair Dealing under the UNIDROIT Principles, Relevant International Conventions, and National Laws" (1995) 3:1 Tul J Intl \& Comp L 47 at 61. Note, however, in Industrial \& General Trust Ltd v Tod, 73 NE 7 at 9 (NYCA 1905), the Court opines in the context of a common law contract as follows: "[n]o covenant of immunity can be drawn that will protect a person who acts in bad faith, because ... the courts will not enforce it." See also Paul MacMahon, "Good Faith and Fair Dealing as an Underenforced Legal Norm" (2015) 99:6 Minn L Rev 2051 at 2108. Restatement (Second) of Contracts $\$ 205 \mathrm{cmt}$ a (1981).

Ibid, cmt d.

See generally Miller \& Perry, supra note 165 .

Robert S Summers, “'Good Faith' in General Contract Law and the Sales Provisions of the Uniform Commercial Code" (1968) 54:2 Va L Rev 195 at 201. 
reasonableness of the community and not on the individual's own beliefs as to what might be decent, fair or reasonable. Both common sense and tradition dictate an objective standard for good faith performance. ${ }^{178}$

Steven Burton offers a third view, namely that good faith is breached when a contracting party attempts to recapture an opportunity that is foregone as a consequence of entering into the contract. ${ }^{179}$

Not only is there controversy on the academic front. There is no agreement amongst judges as to what good faith entails. As Paul MacMahon states, "[i]t is admittedly difficult to provide a comprehensive account of the case law on good faith performance, because there is no generally accepted doctrinal framework, and many decisions rely on judicial or jury intuition to distinguish between good faith and bad faith performance." 180 Suffice it to say that the meaning of good faith "is notoriously unclear" ${ }^{181}$ with Judge Posner opining that the cases "are cryptic" as to what good faith requires though "emphatic about its existence."182 Beyond this, judges make their rulings in the particular business contexts before them involving parties that have specific knowledge of some facts, and imperfect or no knowledge of other facts, and whose actions may be ambiguous as to motive or intent. Taken all together, it is no surprise that courts across the US are not consistent in how the obligation of good faith is applied in breach of contract cases.

For example, though there is a clear majority perspective, there is nonetheless a judicial divide on the question of whether the obligation of good faith is independent of and in addition to the express terms of the contract, or, conversely, whether the obligation is only relevant in determining whether a term of the contract has been breached. On this front, Edward Imwinkelried surveyed published cases from the 1990s through $2009 .{ }^{183}$ He found that most jurisdictions follow the latter approach, citing judicial language such that " $[\mathrm{t}] \mathrm{he}$ complaining party cannot rely on the implied obligation to enlarge or expand his or her express contract rights" 184 and "[t]he alleged violation of the implied obligation does not constitute a separate contract claim supporting an independent contract cause of action."185

E Allan Farnsworth, "Good Faith Performance and Commercial Reasonableness Under the Uniform Commercial Code" (1963) 30:4 U Chicago L Rev 666 at 672.

Steven J Burton, "Breach of Contract and the Common Law Duty to Perform in Good Faith" (1980) 94:2 Harv L Rev 369 at 373.

MacMahon, supra note 173 at 2066. See also Burton, ibid at 369, who observes that courts and commentators have not "articulated an operational standard that distinguishes good faith performance from bad faith performance."

MacMahon, ibid at 2051.

Market Street Associates LLP v Frey, 941 F (2d) 588 at 593 (7th Cir 1991), cited by Jay M Feinman, "Good Faith and Reasonable Expectations" (2014) 67:3 Ark L Rev 525 at 525. Note that Feinman criticizes such a view, arguing that the obligation of good faith is based on a misunderstanding that "good faith is a special doctrine that does not easily fit within the structure of contract law" at 525 . Edward J Imwinkelried, "The Implied Obligation of Good Faith in Contract Law: Is it Time to Write Its Obituary?" (2009) 42:1 Tex Tech L Rev 1 at 9.

Ibid at 11, quoting Broder v Cablevision Systems Corp, 329 F Supp (2d) 551 (SDNY 2004).

Imwinkelried, ibid at 12 . See cases cited by Imwinkelried in his footnotes 120-21. For example, Imwinkelried cites LaPosta Oldsmobile Inc v General Motors Corp, 426 F Supp (2d) 346 (NDW Va 2006) which involved both West Virginia and Michigan law. The Court stated as follows: "GM's view is consistent with West Virginia law [that] ... "the implied covenant of good faith and fair dealing cannot give contracting parties rights which are inconsistent with those set out in the contract" at 355 [citation omitted]. He further stated that "Michigan law does not recognize a claim for breach of an implied covenant of good faith and fair dealing" at 355 [citation omitted]. See also the analysis of UCC § 1-304 (2001) in note 163, supra. 
Only a minority find an independent obligation of good faith, and those primarily in the area of franchise contracts. ${ }^{186}$

\section{RELAXING The Obligation OF GoOd FAITH}

Alan Miller and Ronen Perry observe that "[ $t]$ he prevailing view in American courts is that a disclaimer of the common-law duty of good faith violates public policy, and therefore has no legal effect." ${ }^{187}$ Likewise, the UCC forbids the parties from disclaiming good faith. But, as noted earlier, $\S 1-302$ (b) of the UCC permits the parties to "determine the standards by which the performance of those obligations is to be measured" provided those standards are not "manifestly unreasonable." While application of this section may vary from state to state, some general commentary is possible.

There are many illustrations under UCC $§ 1-302$ wherein one party challenges a contractual clause that purports to vary UCC default rules on the basis that the impugned clause is manifestly unreasonable. Examples include variations of time limits, ${ }^{188}$ remedies available to a lessor, ${ }^{189}$ and protection of debtors' interest in collateral. ${ }^{190}$ Case law specifically on the issue of varying the good faith standard itself is considerably more difficult to find. One example, however, is the 2012 Colorado case of Wells Fargo Bank $v$. Khan, ${ }^{191}$ wherein the lender's attempt to alter the good faith standard by contract was contested. More specifically, at issue inter alia was whether the guarantors (the Khans) had enforceably waived UCC good faith (by way of section 5(h) of the impugned Guarantee ${ }^{192}$ ) such that the guarantors' counterclaim against the lender for breach of good faith should be dismissed. The Court declined to dismiss for several reasons. First, while there was no case from Colorado directly on point, the Court opined that "Colorado courts would likely conclude that parties may not waive the duty of good faith and fair dealing"193

For the minority view in the context of a franchise agreement, Imwinkelried, ibid, cites the bankruptcy appeal of Re Vylene Enterprises Inc, 90 F (3d) 1472 at 1477 (9th Cir 1996), citing Eichman v Fotomrt Corp, 880 F (2d) 149 at 164 (9th Cir 1989): “"Where there is no express grant of an exclusive territory in a contract or franchise agreement, none will be impliedly read into the contract.' Notwithstanding, under California law, all contracts have an implied covenant of good faith and fair dealing." While the franchisee in this case did not have an exclusive territory franchise agreement, the Court found that the franchisor's construction of a competing restaurant within a mile and a half of the franchisee's restaurant was a breach of the covenant of good faith and fair dealing. According to the Court: "[ $\mathrm{t}] \mathrm{h}$ he bad faith character of the move becomes clear when one considers that building the competing restaurant had the potential to not only hurt Vylene, but also to reduce Naugles' royalties from Vylene's operations" at 1477.

American Licorice Co v Total Sweeteners Inc, 2014 US Lexis 150122 (ND Cal) (45 day limitation for notification of breach); Southland Health Services Inc v Bank of Vernon, 887 F Supp (2d) 1158 (ND Ala 2012) (a shortening of the period in which a customer must report unauthorized account transactions to the bank); Absolute Drug Detection Services Inc v Regions Bank, 116 So (3d) 1162 (Ala App Ct 2012) (time limits in a bank deposit agreement). Barr International Inc v Paradise Produce Company, Inc, 64 UCC Rep Serv (2d) 867 (Super Ct Del 2008).

190 Etelson v Suburban Trust Co, 283 A (2d) 408 (Ct App Md 1971) (decided under UCC § 1-102(3), the predecessor section to current $\S 1-302$ ).

1912012 US Lexis 180092 (Dist Ct Co 2012).

192 Section $5(\mathrm{~h})$ of the guarantee, ibid at 7 , provides:

Indemnitor hereby consents and agrees that ... the liability of Indemnitor under this Agreement shall be unconditional and absolute and shall in no way be impaired or limited by ... the taking or failure to take any action of any type whatsoever. No such action which Lender shall take or fail to take in connection with the Loan Documents or any collateral for the Loan, not any course of dealing with Borrower or any other person, shall limit, impair or release Indemnitor's obligations hereunder, affect this Agreement in any way or afford Indemnitor any recourse against Lender. Ibid at 9 . 
on public policy grounds associated specifically with contracts of guarantee. Second, and even assuming it were possible to waive or otherwise reduce good faith obligations, the clause purporting to do so failed to hit its mark. According to the Court:

The Khans cite Colo. Rev. Stat. $§ 4-1-302$ for the general provision that parties may vary the CUCC [Colorado Uniform Commercial Code] in any manner pursuant to a mutual agreement. However, this section also states that " $[\mathrm{t}]$ he obligations of good faith, diligence, reasonableness, and care prescribed by this title may not be disclaimed by agreement." Colo. Rev. Stat. § 4-1-302(b)... [I]n reviewing the plain language of $\S 5(\mathrm{~h})$ of the Guaranty Agreement in this case, I find that it is questionable as to whether this provision sets forth an express waiver of the duty of good faith and fair dealing. Neither the terms "good faith" and "fair dealing" [*13] nor the term “waiver" appear in the cited provision. Thus, I deny Wells Fargo's argument that the Khans expressly waived any right of recourse to assert their Good Faith Counterclaim against Wells Fargo under the Guaranty Agreement. ${ }^{194}$

Setting aside express waiver, consider Thomas Diamond and Howard Foss's observation that the UCC permits the parties to "indirectly waive" protection of the good faith provision "by expressly authorizing particular conduct." 195 Indeed, one strategy in relation to $\$ 1-302$ (b) is for the contract to simply define what one party can and cannot do. For example, a contract might grant one party a discretion (the exercise of which is expressly unfettered), and through such a clause, attempt to pre-emptively close the door on allegations of bad faith by way of agreement. Kham \& Nate's Shoes No. 2 Inc. v. First Bank of Whiting ${ }^{196}$ (a wellknown 1990 case which involves both the UCC and bankruptcy law) is one such instance. Kham concerned, inter alia, the propriety of the lender's decision to terminate the borrower's line of credit. At the lower level, Bankruptcy Judge Coar ruled that the lender's decision to terminate was in breach of contract: "there existed no valid business reason to terminate the line of credit because the bank was fully secured, received timely payment on its debt, and had the complete cooperation of the Debtor." ${ }^{197}$ Accordingly, there was a breach under UCC $\S 1-203$ (1989). ${ }^{198}$ On appeal, the district court affirmed Judge Coar's decision though on somewhat different grounds. ${ }^{199}$ On further appeal, the US Court of Appeals, Seventh Circuit reversed, expressly finding no breach of good faith. In short, the contract in question empowered the lender to cancel the plaintiff's line of credit simply by giving five days' notice. There were no other strictures or additional pre-conditions, with the agreement further stating that "nothing provided herein shall constitute a waiver of the right of the Bank to

Ibid at 8. Based on this analysis, the Court did not expressly consider whether the impugned clause was "manifestly unreasonable" under the Colorado Uniform Commercial Code. The wording of Colo Rev Stat tit $4 \S 4-1-302$ (2015), which follows the UCC wording, provides as follows:

Variation by agreement

(a) Except as otherwise provided in subsection (b) of this section or elsewhere in this title, the effect of provisions of this title may be varied by agreement.

(b) The obligations of good faith, diligence, reasonableness, and care prescribed by this title may not be disclaimed by agreement. The parties, by agreement, may determine the standards by which the performance of those obligations is to be measured if those standards are not manifestly unreasonable.

Thomas A Diamond \& Howard Foss, "Proposed Standards for Evaluating When the Covenant of Good Faith and Fair Dealing Has Been Violated: A Framework for Resolving the Mystery" (1996) 47:3 Hastings LJ 585 at 624 .

908 F (2d) 1351(7th Cir 1990) [Kham].

Re Kham, 97 BR 420 at 428 (Bankr Ill 1989).

Ibid.

First Bank of Whiting v Kham \& Nate's Shoes No 2, Inc, 104 BR 909 (ND Ill 1989). 
terminate financing at any time." 200 Writing through Judge Easterbrook, the appellate court stated:

Firms that have negotiated contracts are entitled to enforce them to the letter, even to the great discomfort of their trading partners, without being mulcted for lack of "good faith". Although courts often refer to the obligation of good faith that exists in every contractual relation ... this is not an invitation to the court to decide whether one party ought to have exercised privileges expressly reserved in the document. "Good faith" is a compact reference to an implied undertaking not to take opportunistic advantage in a way that could not have been contemplated at the time of drafting, and which therefore was not resolved explicitly by the parties. When the contract is silent, principles of good faith - such as the UCC's standard of honesty in fact, UCC Sec. 1-201(19), and the reasonable expectations of the trade, UCC Sec. 2-103(b) (a principle applicable, however, only to "merchants", which Bank is not) - fill the gap. They do not block use of terms that actually appear in the contract. ${ }^{201}$

For the appeals court, there could be no breach of good faith when one is simply exercising a contractual right pursuant to its terms. Accordingly, though the "contracting out" provision of UCC §1-302 was never expressly mentioned by the Court, it arguably loomed in the background nonetheless. Viewed from this perspective, the parties had successfully varied the UCC obligation of good faith by virtue of the unfettered termination clause in favour of the lender. To use the language of UCC $\$ 1-302$, the parties had functionally determined "the standards by which the performance of those obligations" was to be measured in a way that was not "manifestly unreasonable." In short, the Court enforced the contract according to its terms.

Note that Kham is raised as an example of an enforceable means of limiting good faith in an American jurisdiction. It is beyond the scope of this article to assess whether the discretion clause in Kham would be regarded as completely unfettered and enforceable by a Canadian court. ${ }^{202}$

Kham has been subject to criticism by American scholars for being literalist and textualist. As Burton observes, Judge Easterbrook "posed two alternatives: interpret literally or open the door to requirements of kindness and Monday morning quarteringbacking by judges and jurors." ${ }^{203}$ Dennis Patterson is even more withering: "The opinion in Kham is replete with statements that could have been uttered by any proponent of nineteenth-century formalism." ${ }^{204}$ However, it is also the case that the Easterbrook approach has been followed

Kham, supra note 196 at 1353.

Ibid at 1357. The Court did acknowledge that the bank made a technical error in giving notice: the contract called for telephone and written notice while the lender only gave written notice (at 1359).

For commentary on the status of the Canadian law regarding the exercise of a contractual discretion, see Justice Cromwell's assessment in Bhasin SCC, supra note 1 at para 89: "courts have required that discretionary powers not be exercised in a manner that is 'capricious' or 'arbitrary'.... In other contexts, this Court has been reluctant to extend the requirements of good faith beyond honesty for fear of causing undue judicial interference in contracts" [citations omitted].

Steven J Burton, "Good Faith in Articles 1 and 2 of the U.C.C.: The Practice View" (1994) 35:4 Wm \& Mary L Rev 1533 at 1550.

Dennis M Patterson, "A Fable from the Seventh Circuit: Frank Easterbrook on Good Faith" (1991) 76:3 Iowa L Rev 503 at 515 . 
by subsequent courts. ${ }^{205}$ As Michael Van Alstine notes, it is fair to conclude that Kham "marked a significant change in the course of the law."

The Kham line of authority is not without rivals, however. In arriving at its decision in Kham, the appellate court declined to follow KMC Co. v. Irving Trust Co. ${ }^{207}$ - a case which came to the opposite result on highly similar facts. In KMC Co, the lender refused further advances to the plaintiff borrower without notice and pursuant to a contract that apparently placed no limits on the exercise of that discretion. ${ }^{208}$ The Sixth Circuit upheld the jury's verdict that this conduct was in breach of good faith for acting unreasonably. On appeal of this verdict, the Court rejected the "literal interpretation" 209 urged upon it by the lender because that would leave the borrower "entirely at the whim or mercy [of the lender] absent an obligation of good faith performance." ${ }^{210}$ As succinctly noted by MacMahon, the Court stressed that "the borrower was at the lender's mercy, and that the parties had a long-term banking relationship." 211 Judge Easterbrook, in rejecting the lower court's analysis, declined to adopt the 6th Circuit approach in KMC Co, noting that on the facts of Kham: the "Bank did not create Debtor's need for funds, and it was not contractually obliged to satisfy its customer's desires. The Bank was entitled to advance its own interests, and it did not need to put the interests of Debtor and Debtor's other creditors first." ${ }^{212}$ Judge Easterbook went on to add as follows: "To the extent [KMC Co] holds that a bank must loan more money or give more advance notice of termination than its contract requires, we respectfully disagree. First Bank of Whiting is not an eleemosynary institution. It need not throw good money after bad, even if other persons would catch the lucre." 213

Those seeking to indirectly limit the duty of good faith can indeed look to many instances of American courts allowing one party to exercise its unfettered contractual discretion unhindered, unless there is evidence of bad motive. In the non-UCC case of Wilson $v$. Amerada Hess Corp.,${ }^{214}$ for example, the Court referenced with approval a number of cases leading to the conclusion that bad motive is an additional element necessary to establish breach of good faith in such a circumstance, defined as using the discretionary power to destroy or injure "the right of the other party to receive the fruits of the contract." 215 As the Court in Wilson observes: "Without bad motive or intention, discretionary decisions that

See e.g. Milford-Bennington Railroad Co v Pan Am Railways Inc, 695 F (3d) 175 at 179 (1st Cir 2012), in which the Court stated:

The only issue before us is whether Pan Am's decision to exclude Leishman from its trackage violated the duty of good faith and fair dealing implicit in the Agreement. The district court granted summary judgment to Pan Am, holding that the Agreement "plainly gives it the right to act as it did, regardless of its motive for doing so. Under the circumstances, MBR cannot rely on the duty of good faith and fair dealing to restore a right that it bargained away by agreeing to the [Agreement] [citations omitted].

For a case that expressly relies on Kham, see Baxter Healthcare Corp v OR Concepts Inc, 69 F (3d) 785 at 792 (7th Cir 1995).

Michael P Van Alstine, "Of Textualism, Party Autonomy, and Good Faith" (1999) 40:4 Wm \& Mary L Rev 1223 at $1260-61$.

KMC Co v Irving Trust Co, 757 F (2d) 752 (6th Cir 1985) [KMC Co].

Ibid at 761 .

Ibid at 759 .

Ibid.

MacMahon, supra 173 at 2066.

Kham, supra note 196 at 1358.

Ibid.

773 A (2d) 1121 (NJ 2001) [Wilson].

Sons of Thunder Inc v Borden Inc, 690 A (2d) 575 at 586 (NJ 1997). 
happen to result in economic disadvantage to the other party are of no legal significance."216 Courts have reached similar conclusions in UCC cases involving rejection of goods, ${ }^{217}$ in requirements and output contracts, ${ }^{218}$ and price modifications. ${ }^{219}$ This, of course, places a functional limit on Judge Easterbrook's approach. But it also means that, without more, clauses that purport to grant unlimited discretion will be enforced by the courts, and courts will not substitute their judgment as to commercial reasonableness unless there is evidence of bad motive. In this way, the good faith obligation under the UCC is at least partially obviated by virtue of the parties' agreement, thereby indirectly engaging the protective force of $\S 1-302$.

The Court in Wilson also acknowledged that bad motive might be evident from the exercise of discretion in such a way as to unreasonably deprive the other party of the mutually expected benefits of the contract, thereby acknowledging that good faith does place limits on the exercise of a seeming unfettered discretion. ${ }^{220}$ In Wilson, gas station dealers accused the distributor of breaching the duty of good faith in setting gasoline prices. ${ }^{221}$ The New Jersey Supreme Court established the following test to determine whether the defendant breached a duty of good faith in exercising an apparently unfettered discretion under the contract in question:

\footnotetext{
[A party] breaches the duty of good faith and fair dealing if that party exercises its discretionary authority arbitrarily, unreasonably, or capriciously, with the objective of preventing the other party from receiving its reasonably expected fruits under the contract. Such risks clearly would be beyond the expectations of the parties at the formation of a contract when parties reasonably intend their business relationship to be mutually beneficial. They do not reasonably intend that one party would use the powers bestowed on it to destroy unilaterally the other's expectations without legitimate purpose. $^{222}$
}

The Court reversed the summary judgment granted to the defendant and remanded the matter to the trial court to determine whether the defendant knew from the operations of its own coop stations that its pricing rendered it impossible for plaintiffs to meet their operating expenses and perform profitably, and whether the defendant could provide an explanation for its pricing that did not render the decision arbitrary, capricious, or unreasonable. ${ }^{223}$ The Court also noted that such knowledge would be "difficult to prove."224

In short, the principle of freedom of contract enshrined in US contract law governs the judicial interpretation of clauses granting seemingly unlimited discretion to one of the parties. The UCC and judicial interpretation can clearly favour the enforcement of the parties' bargain as they have expressed it. As MacMahon states, "[a]s a matter of current practice, many exercises of contractual discretion get fairly light scrutiny under the doctrine of good faith and fair dealing.... Usually, if a defendant so much as offers a legitimate reason for her

$\begin{array}{ll}216 & \text { Supra note 214 at } 1130 . \\ 217 & \text { Cavendish Farms Inc v Mathiason Farms Inc, } 792 \text { NW (2d) } 500 \text { (Sup Ct N Dak 2010). } \\ 218 & \text { Northern Natural Gas Co v Conoco Inc, 986 SW (2d) 603 (Sup Ct Tex 1998). } \\ 219 & \text { Allapattah Services Inc v Exxon Corp, 61 F Supp (2d) 1308 (SD Fla 1999). } \\ 220 & \text { Wilson, supra note 214 at 1131. } \\ 221 & \text { Ibid. } \\ 222 & \text { Ibid at 1130. } \\ 223 & \text { Ibid at 1132. } \\ 224 & \text { Ibid at } 1131 .\end{array}$


decision, she will escape liability."225 However, in limited circumstances, when the underlying motive of one of the parties belies the basic premise that parties should be able to rely on their reasonable commercial expectations, courts will find that the obligation of good faith has been breached regardless of how the contract is drafted. ${ }^{226}$ In such a case, expressly authorizing a particular kind of conduct will not automatically sanitize it. Likewise, and as Diamond and Foss observe:

\begin{abstract}
Although a grant of absolute discretion with regard to specific conduct would waive the covenant of good faith, it would not deprive the courts of the ability to find that the conduct violated public policy. In an employment contract terminable at will, for example, an employer's decision to terminate an employee because of the employee's race may be held to violate public policy, and for that reason could be prohibited, irrespective of the fact that the covenant had been waived. ${ }^{227}$
\end{abstract}

The exculpatory clause is also a crucial means by which parties relax the standard of good faith performance and functionally engage the protection of UCC $\$ 302$. That is, conduct that might otherwise be characterized as bad faith is sheltered from scrutiny by virtue of the parties' agreement. Exculpatory clauses that purport to exclude liability of one of the parties are disfavoured, but are generally enforceable unless:

(1) [the clause] is either ambiguous in scope or purports to release the benefited party from liability for intentional, willful, or wanton acts

(2) there was a disparity of bargaining power between the parties; [or]

(3) the types of services being offered or provided (taking into consideration whether it is a public or an essential service). ${ }^{228}$

As in Canada, exculpatory clauses that violate public policy are unenforceable.

The Connecticut case of Brown v. Soh ${ }^{229}$ provides an example of an exculpatory clause falling on the grounds of public policy. In Brown, a car racing school required all employees and students to sign an exculpatory clause before they would be permitted to enter the restricted driver training area where new drivers would practice. When an employee was injured in that restricted area, the car racing school attempted to avoid liability pursuant to

MacMahon, supra note 173 at 2104 [footnotes omitted].

See e.g. Emerson Radio Corp v Orion Sales Inc, 253 F (3d) 159 at 170 (3rd Cir 2001):

This obligation to perform contracts in good faith has been interpreted in New Jersey to mean that "neither party shall do anything which will have the effect of destroying or injuring the right of the other party to receive the fruits of the contract... New Jersey law also holds that a party to a contract can breach the implied duty of good faith even if that party abides by the express and unambiguous terms of that contract if that party 'acts in bad faith or engages in some other form of inequitable conduct" [citations omitted].

Diamond \& Foss, supra note 195 at 627 [footnotes omitted].

Schlobohm v Spa Petite Inc, 326 NW (2d) 920 at 923 (Sup Ct Minn 1982) [citations omitted].

Brown v Soh, 909 A (2d) 43 (Sup Ct Conn 2006) [Brown]. 
the exculpatory clause. The Court responded that the exclusion clause was unenforceable. As the Court observed: "We further note that an employer, in this case the racing school, possesses a decisive advantage of bargaining strength against the plaintiff employee. Considering the "economic compulsion facing those in search of employment ... [t]o suppose that [a] plaintiff ... had any bargaining power whatsoever defies reality." "230 The Court concluded that exculpatory agreements are "almost universally rejected in the employment context, where exculpatory agreements exempting an employer from all liability for negligence toward his employees [are] void as against public policy." ${ }^{231}$ In short, context is crucial when assessing the force of an exclusion of liability clause. And in this way, the Court signals a clear limit to the reach of such a clause and, by implication, a limit on the extent to which good faith under the UCC might be successfully relaxed.

Similarly, and as in Canada, damage limitations and warranty disclaimers are unenforceable under the UCC if they are unconscionable. ${ }^{232}$ For example, in Industralease Automated \& Scientific Equipment Corp. v. R.M.E.E., ${ }^{233}$ the parties entered into an equipment lease. The terms of the lease included a warranty disclaimer, but preserved an express warranty if the lessor was also the equipment manufacturer, which, in this instance, it was. ${ }^{234}$ The defendant-lessee made the necessary preparations for installation of the equipment but the day before the scheduled delivery, the lessee was approached by the plaintiff lessor and "told that the lease he had signed before was 'no good', and that the new papers had to be signed 'so we can get our money so you can get your incinerator." lessee testified that the new papers looked like the first lease except for a different name at the top, so he signed the second lease. Unknown to the lessee, this second lease disclaimed the express warranty that existed in the first lease. ${ }^{236}$ The equipment was installed but was never functional. On this basis, the lessee refused to make lease payments and the lessor sued. ${ }^{237}$ Recognizing that contracting parties "are given broad latitude within which to fashion their own remedies for breach of contract," 238 the New York Supreme Court, Appellate Division nevertheless found that the disclaimer in the second lease was both procedurally and substantively unconscionable. The Court observed that:

The atmosphere of haste and pressure on the defendants is clearly pervasive. In addition, at this point of the bargaining, with the beginning of the season for the defendants' operations at hand, the defendants were clearly at a disadvantage to bargain further and, indeed, did not profess to understand the size and mechanism of the equipment which would satisfy their needs.... Although the statute prescribes that we are to determine unconscionability as of the time of the making of the contract, we cannot divorce entirely the events which occur later. In this case, the evidence plainly establishes that the equipment did not work at all, that it

Ibid at 49, quoting White v Homewood (Village of), 628 NE (2d) 616 (Ill App Ct 1993). Brown, ibid.

UCC § 2-719(3) (“Consequential damages may be limited or excluded unless the limitation or exclusion is unconscionable. Limitation of consequential damages for injury to the person in the case of consumer goods is prima facie unconscionable but limitation of damages where the loss is commercial is not.") 396 NYS (2d) 427 (Sup Ct App Div 1977).

Ibid at 428 .

Ibid.

Ibid.

Ibid at 429.

Ibid at 431 . 
achieved none of the purposes of the parties. This is a result so "one-sided" ... that the disclaimer in good conscience should not be enforced. In effect the equipment was worthless. ${ }^{239}$

The importance of context also explains the general judicial reluctance to enforce a clause that releases liability for intentional wrong doing but there are nonetheless exceptions. Such cases help illuminate how conduct that might otherwise be characterized as bad faith performance can be effectively reframed as going to a risk which the parties addressed and allocated in the subject contract. UCC $\S 302$ is thereby implicitly triggered. For example, in a case reminiscent of the Dragons' Den case discussed earlier, ${ }^{240}$ the Court in Klapper $v$. Graziano $^{241}$ upheld a release that excluded, inter alia, defamation claims against the show known as Mob Wives, or its producers. Though agreeing to be defamed is akin to agreeing to allow the other contract party to be dishonest, freedom of contract can still prevail. In Klapper, a plastic surgeon who appeared on the show and performed surgery on one of the participants was the subject of much negative publicity, including allegations of malpractice and incompetence. However, the Court denied the surgeon's claims of defamation stating that " $[\mathrm{t}]$ he terms of the Release are clear and explicit and there is no public policy that requires this Court to set aside the Release as unfair. The contract entered into by Dr. Klapper was understood and the risks were apparent and obvious." 242 Thus, at least in some circumstances, parties can contract to functionally permit bad faith behaviour. Note too that this Court's assessment is consistent with freedom of contract, a value also emphasized by Justice Cromwell in Bhasin.

In sum, parties to a contract in the US cannot exclude the duty of good faith in an absolute sense but they can effectively reduce its scope by agreement - including by defining the scope of acceptable conduct or by virtue of an exclusion of liability clause or otherwise defining their obligations within judicially acceptable parameters. Absent bad motive, grossly unequal bargaining power, or the intent to deliberately deprive the other party of the expected fruits of a contract, parties are entitled to freedom of contract under $\$ 1-302$ of the UCC.

\section{Conclusion}

As Gunther Teubner notes (in the context of the continental principle of bona fides being imported into British contract law by virtue of the European Consumer Protection Directive 1994), ${ }^{243}$ there are challenges in "concretising" a general principle. ${ }^{244}$ This assessment resonates at least somewhat with the challenge posed by Bhasin: it is difficult to predict exactly where the good faith principle will take Canadian common law and the extent to which the duty of honesty can be reduced, if at all. But with that said, in the admittedly limited time since Bhasin came down, no new contract law duties or doctrines have been

\footnotetext{
239 Ibid at 432 [citations omitted].

$240 \quad$ MHR Board Game Design, supra note 142.

241970 NYS (2d) 355 (Sup Ct 2013) [Klapper].

242 Ibid at 363.

243 See The Unfair Terms in Consumer Contracts Regulations 1994, SI 1994/3159, s 4, implementing EC, Council Directive 93/13/EEC of 5 April 1993 on unfair terms in consumer contracts, [1993] OJ, L95/29, referenced in Gunther Teubner, "Legal Irritants: Good Faith in British Law or How Unifying Law Ends Up in New Divergences" (1998) 61:1 Mod L Rev 11 at 11.

244 Ibid at 19. Teubner makes this comment in the context of The Unfair Terms in Consumer Contracts Regulations 1994, ibid, which "transplanted the continental principle of bona fides directly into the body of British contract law" at 11.
} 
recognized by the Canadian judiciary. If this trend holds, the principle of good faith is likely to be more prominent in explaining and defending existing common law doctrine concerning good faith than it is in opening new and unfamiliar frontiers. Significantly, because the Supreme Court of Canada in Bhasin endorses the good faith principle, it also regularizes and even officially legitimates - the types of situations and relationships where good faith in contractual performance have already been enforced. This in itself can be regarded as revolutionary from a common law perspective. In short, and with freedom of contract as a mandatory part of the backdrop, the bona fides of good faith in common law Canada cannot be seriously contested. 